\title{
PANELÁK JAKO VÝSLEDEK VĚDECKOTECHNICKÉHO EXPERIMENTU
}

\author{
EVA NOVOTNÁ \\ Ústav pro dějiny umění Filozofické fakulty Univerzity Karlovy \\ eva.novocha@gmail.com
}

\begin{abstract}
Panelak as a product of the scientific experiment

The article deals with the history of prefabricated houses (panelaks) in the context of Czechoslovakian construction industry at the turn of the 50's and 60's. It focuses on the historical, ideological and material aspects of the development and seeks further influences in political and social issues of that time, including a short excursion to the Soviet Union. The article pays main attention to construction experiments (especially monoliths) and the invention of housing districts (estates) of the time.
\end{abstract}

Keywords: Czechoslovakia - architecture and urbanism history - housing construction thaw - prefab - experimental buildings - housing estate - monolith

„Vzhledem $k$ významu, který má úroveň bydlení v životě a výchově socialistického člověka, je třeba při dlouhodobém plánování a projektování mít na žreteli, že novou bytovou výstavbou vytváríme podmínky života lidí v komunistické společnosti.“1 (Oldřich Černík, 1959)

\section{„Architektura tání" v Sovětském svazu a v zemích socialistického tábora}

Pozornost, kterou stát věnoval na přelomu padesátých a šedesátých let bydlení a bytové výstavbě, souvisela do velké míry se změnami v hospodářské a sociální politice Československa. V této souvislosti stojí za to nahlédnout do dění v Sovětském svazu a v ostatních zemích socialistického bloku.

Bydlení a hromadná bytová výstavba, v éře destalinizace spojené s nástupem Nikity Sergejeviče Chruščova, v druhé polovině padesátých let jednoznačně nabyly nového významu. Odklon od socialistického realismu, důsledné zprůmyslnění výrobních i stavebních procesů, masové používání prefabrikátů, zejména železobetonových panelů, a důraz na dostupnost a vyšší úroveň bydlení zrcadlily nebo dokonce zhmotňovaly ideje nového

1 Z projevu soudruha Oldřicha Černíka na zasedání ÚV KSČ - Vyřešení bytového problému - všenárodní úkol, Československý architekt V, 1959, č. 6, s. 1. - Má stat vychází z dizertační práce Eva Novotná, Česká bytová výstavba 1958-1970: Stát - ideologie - architektura - lidé, Ústav pro dějiny umění FF UK, Praha 2019. 
Chruščovova Sovětského svazu. Hlavní politické události, vystoupení Nikity Chruščova proti doktríně socialistického realismu a závěry XX. (1956), XXI. (1959) a XXII. (1961) sjezdu Komunistické strany Sovětského svazu jednoznačně hýbaly i naším prostředím.

O významných změnách v sovětském stavebnictví a slavném Chruščovově projevu na moskevské Konferenci pracovníků ve stavebnictví v prosinci roku 1954 informovaly české architekty publikace Výzkumného ústavu výstavby a architektury a publikace Svazu československých architektů $\mathrm{z}$ roku $1955 .^{2} \mathrm{~V}$ předmluvě první $\mathrm{z}$ nich se píše: „Moskevskou konferencí pracovníků ve výstavbě byly nám včas odhaleny nesprávné tendence, které se projevovaly v naší výstavbě a architektuře." 3 Dále se zde, podobně jako v Sovětském svazu, kritizuje „ozdobnictvi“ a dosavadní „zúžené chápání ideových otázek jako otázek výlučně výtvarných". ${ }^{4}$

Zcela v souladu s děním v SSSR vydává téhož roku Komunistická strana Československa usnesení $\mathrm{O}$ opatřeních ke zprůmyslnění a dalšímu rozvoji stavebnictví, které nařídilo zmodernizovat typové podklady pro bytovou výstavbu. Nové typy sledovaly trendy sovětského stavebnictví - unifikaci konstrukčních prvků, proudovou metodu stavění a výrobu železobetonových prefabrikátů, at už menších blokopanelů, anebo rozměrných panelů celostěnových. Následovaly výzkumy nových konstrukčních metod a moderních materiálů a technologií, z nichž mnohé pak ověřily experimentální stavby z let 1959-1963.

Právě politické a ideologické změny v sovětském bloku se v druhé polovině padesátých let významně podílely na formování bytové výstavby u nás. Změna kurzu směrem $\mathrm{k}$ důslednému zprůmyslnění stavebních postupů v podstatě jen posílila vlastní bohaté zkušenosti s typizací a standardizací bydlení i s experimenty s panelovými technologiemi v Gottwaldově. Československo a Sovětský svaz v šedesátých letech sdílely novinky v technice, moderní architektuře a urbanismu celých sídlišt a vzájemně se ujištovaly o správné cestě k vyšší kultuře bydlení. V rámci „mírového soutěženi“ mezi Východem a Západem pak celý sovětský blok sledoval rychlý růst životní úrovně, nejmodernější obytné soubory a technologie za železnou oponou.

Rozhodující význam pro liberalizaci poměrů v Sovětském svazu a pro následné „táni““ v celém východním bloku měl XX. sjezd KSSS v roce 1956, na kterém Nikita Sergejevič Chruščov odsoudil Stalinův kult osobnosti a odkryl zločiny padesátých let i základní ideologické omyly Stalinova pojetí marxismu-leninismu.

Po Chruščovově „tajném“ proslovu se stranické orgány nejen na domácí půdě, ale i v ostatních satelitech snažily výrazně posílit vlastní legitimitu i obraz samotného socialismu a komunismu. Právě otázky bydlení a společenské spotřeby, jak píše americký historik Steven E. Harris, hrály klíčovou roli v konsolidaci Sovětského svazu a ostatních zemí socialistického bloku v období po Stalinově smrti.

Kampaň na řešení bytového problému Chruščov otevřel v roce 1957. Sliboval v ní, že díky hromadné výstavbě moderních panelových domů, později familiárně pojmenovaných chruščovky, a výstavbě rozsáhlých sídlišt bude každá rodina v nejbližších deseti až

2 II. všesvazový sjezd sovětských architektů. Sborník přeložených materiálů, Praha 1955. - Diskuse o otázkách soudobé výstavby a architektury v SSSR II, VÚVA Praha 1955.

3 Diskuse o otázkách soudobé výstavby a architektury v SSSR I, VÚVA Praha 1955, s. 14.

4 Ibidem, s. 11. 
dvanácti letech bydlet v samostatném bytě. ${ }^{5}$ Odliv nájemníků ze sdílených bytů, komunálek, do malých bytů v panelácích, kde měli lidé konečně soukromí a mohli žít vlastní život, podle Harrise doslova symbolizuje celkové „tání“ a uvolnění společenských poměrů v průběhu Chruščovovy vlády. ${ }^{6}$

Vlastní domov a životní prostor znamenal pro mnoho Rusů nejen nebývalý komfort, ale i konec společenské kontroly a dohledu, jak to zajímavě popisuje v jednom ze vzpomínkových záznamů spisovatelka Světlana Alexijevičová: „Veškerý život v letech šedesátých se odehrával v kuchyni. Diky Chruščovovi! Za něj jsme zrušili společné byty a zř́dili si vlastní kuchyně, v nichž bylo možné nadávat na vládu a hlavně se nebát, protože v kuchyni jsou všichni našinci. Vznikaly tam velké myšlenky a fantastické plány! Kolovaly vtipy. "7 Dnes, kdy hrozí většině těchto panelových sídlišț v Moskvě demolice, se objevují názory, že panelové domy této éry nelze vnímat jen jako přežitý sociální program, pouhé ubytování pro masy. Philipp Meuser, autor publikace o sovětské hromadné výstavbě, podobně zmiňuje, že dnes jsou tyto domy, celá sídliště a bydlení v nich součástí kultury, př́iběhů několika generací. ${ }^{8}$

\section{Nové Čerjomušky}

Vrat'me se však k původnímu obsahu chruščovek v pozdních padesátých a šedesátých letech, $\mathrm{k}$ řešení bytového problému formou socialistického modernismu. Kultura bydlení v panelových sídlištích a růst životní úrovně fungovaly v jakémsi druhém plánu jako významný argument pro vítězství socialismu a pro jeho morální nadvládu nad kapitalismem. Kompletně vybavené obytné soubory s obchody, službami, školkami a sportovišti a upravenou zelení navíc naplňovaly představu o životních podmínkách v blízkém komunismu. ${ }^{9}$ Také u nás se moderní „obytné okrsky“ a „obvody“, jinými slovy rozsáhlá plně vybavená sídliště pro několik desítek tisíc obyvatel, považovaly za „výhonky komunismu“ ${ }^{10}$ Prozrazuje to i řada rezolucí Ústředního výboru KSČ, včetně pokynů strany k soutěži na projekty obytných domů z roku 1959, které mluví o „kultuře bydlení v přechodu od socialismu ke komunismu“. K návrhu na soutěž se konkrétně píše: „Jde v podstatě o to, aby formy bydlení v nadcházejícím období [po roce 1965] cílevědomě napomáhaly těm společenským procesưm, které vedou ke komunismu. Kulturní význam bytové výstavby není jenom $v$ tom, že rozmnožuje hmotné bohatství naši společnosti a prispívá ke zvyšování životní úrovně, ale i v tom, že má vliv na organizaci osobního a společenského

5 Steven E. Harris, Communism on Tomorrow Street. Mass Housing and Everyday Life after Stalin, Baltimore 2013, s. 191-192.

${ }^{6}$ Ibidem, s. 5-6.

7 Světlana Alexijevičová, Doba $z$ druhé ruky, Př́íbram 2015, s. 22.

8 Philipp Meuser - Dimitrij Zadorin, Towards a Typology of Soviet Mass Housing. Prefabrication in the USSR 1955-1991, Berlin 2015.

9 Komunismu měl Sovětský svaz dosáhnout v roce 1980. Konkrétní plán $\mathrm{k}$ naplnění této vidiny představil Chruščov na XXII. sjezdu strany v roce 1961.

10 O tento Leninův pojem se opírá řada dobových textů, u nás zejména na stránkách časopisu Nová mysl. V souvislosti s prezentací obytných okrsků jako „výhonků komunismu“ v sovětských časopisech jej zmínil i Steven E. Harris (pozn. 5), s. 193. 
života." 11 Návrh vyzval také řadu odborných institucí i příbuzných rezortů k výzkumům, které by přinesly aktualizovanou podobu socialistického bydlení s rysy budoucího života v komunismu (viz úvodní citát Oldřicha Černíka). Architekti i odborníci měli sledovat zejména otázky populačního vývoje, změny způsobu života, stravování, práce a péče o děti. Moderní socialistické bydlení, architektura a urbanismus sídlišt̀ skutečně hrály významnou roli v utváření „nového člověka komunistické epochy“, jak deklamovala i řada ekonomů šedesátých let.

V Moskvě v té době jeden vzorový experiment již stál - obytný okrsek č. 9 v Nových Čerjomuškách, dokončený roku 1957 [obr. 1]. K jeho moderní architektuře, vybavení i kompozici se pochvalně vyjádřili dokonce mnozí zahraniční delegáti kongresu Mezinárodní unie architektů (UIA), který Moskva hostila o rok později. Toto malé vzorové sídliště do jisté míry předurčilo podobu projektů z šedesátých let v celém východním bloku. Architekt Jiří Voženílek, předseda Státního výboru pro výstavbu, v roce 1960 důrazně doporučuje našim experimentům „poučit se v Čerjomuškách“ a zaměřit pozornost na projekty moderních plně vybavených okrsků. Kromě sovětských vzorů jsme měli čerpat také z úspěchu československých týmů ve velké mezinárodní soutěži na obytný obvod jihozápadní části Moskvy z přelomu let 1958 a $1959 .{ }^{12}$

S hromadnou výstavbou montovaných panelových domů se v Rusku v době Nových Čerjomušek teprve začínalo. Jen některé domy v okrsku č. 9 tvořily celostěnové panely. Plány však počítaly s tím, že podíl panelových konstrukcí v letech 1959-1965 vzroste z tří procent na 63 procent $\mathrm{z}$ celkové bytové výstavby. V Moskvě a Leningradě se panelové domy údajně v prvním roce stavěly dokonce v 80 procentech. Pro porovnání dodejme, že českoslovenští plánovači nezůstali pozadu a navyšovali podíl panelových domů v letech 1959-1965 z 25 na 73 procent. ${ }^{13}$ Domnívám se, že v té době jsme v podstatě byli v industrializaci stavebnictví a využívání železobetonových konstrukcí ze zemí východního bloku nejdál.

Za realizací experimentálního okrsku v Čerjomuškách stála moskevská Architektonicko-konstrukční kancelář (SAKB) a Akademie architektury a výstavby SSSR, které se podílely také na experimentálních stavbách pro Leningrad a Kyjev nebo na experimentálním rajónu v Čeljabinsku. ${ }^{14}$ Současně na experimentech pracoval Ústřední výzkumný ústav pro experimentální plánování bytové výstavby (CNIIEP), který vznikl již v roce 1949. Za Chruščova tento ústav podporoval výstavbu paneláren v satelitních zemích,

11 Národní archiv (dále NA), fond KSČ-ÚV-K 1945-1989, Komise pro řešení bytového problému 10/22, sv. 1, a. j. 4, zasedání 16. 9. 1959, bod 7: Návrh na uspořádání soutěže na projekty obytných domů z hlediska kultury bydlení v přechodu od socialismu ke komunismu, fol. 1-10.

12 NA, fond KSČ-UUV-K 1945-1989, Komise pro řešení bytového problému 10/22, sv. 2, a. j. 9, zasedání 23. 5. 1960, Zpráva o komplexním vyhodnocení pokusných projektů bytové výstavby (Jiří Voženílek, Státní výbor pro výstavbu), s. 21. - Projekty pro soutěž na obytný rajón zpracovávaly dva architektonické týmy: kolektiv Krajského projektového ústavu (KPÚ) Brno a Gottwaldov, vedený Zdeňkem Chlupem, a kolektiv KPÚ Bratislava a Praha vedený Štefanem Svetkem. Více viz Architektura ČSSR IXX, 1960, č. 9, s. 585-634.

13 Zpráva uvádí také zajímavé údaje o zvýšení podílu družstevní formy výstavby bytů plánované na roky 1961-1965: NDR měla dosáhnout podílu družstev ve $46 \%$ bytové výstavby, Polsko $36 \%$, Madarsko 21 \% a ČSSR $25 \%$. NA, fond KSČ-ÚV-K 1945-1989, Komise pro řešení bytového problému 10/22, sv. 4, a. j. 18, zasedání 29. 12. 1961, Informativní zpráva pro komisi politického byra ÚV KSČ pro řešení bytového problému o zkušenostech z pokrokové bytové výstavby v zahraničí, s. 4 .

14 Alois Kreuzer, Experimentální projekty a stavby pro zajištění hromadné bytové výstavby, Československý architekt V, 1959, č. 15-19, s. 2. 
zejména v Mad’arsku, Rumunsku, ale i v Chile a na Kubě, jak na to upozorňují Hugo Palmarola a Pedro Ignacio Alonso. ${ }^{15} \mathrm{~V}$ této souvislosti autoři rozebírají jednu ze zásadních metod šíření sovětského vlivu v době studené války - export sovětské moci skrze poskytnutou "pomoc“, v tomto případě prostřednictvím panelových domů. Když Chruščov daroval Kubě, zasažené v roce 1963 hurikánem Flora, celou panelárnu, neměl tento dar podle autorů ani tak humanitární charakter, jako spíše rysy kolonialismu. ${ }^{16}$ Díky importované technologii se na Kubě zabydlel koncept opakujících se typů modernistických sídlišt. Samotné paneláky však kubánští architekti velmi tvůrčím zpơsobem přizpůsobili domácím architektonickým tradicím.

Pro srovnání můžeme nahlédnout, do jaké míry přebíraly na konci padesátých let sovětský program hromadné bytové výstavby další země „socialistického tábora“. Vyřešení bytového problému (často do deseti let) vyhlásila tehdy téměř kolektivně jako prioritu většina zemí východního bloku. Řada z nich jako Mad’arsko, Polsko, Rumunsko či Jugoslávie šla cestou „národních“ programů zprůmyslnění a vlastními variacemi na modernistický koncept panelových domů a sídlišst. ${ }^{17}$

\section{Experimenty v Československu 1958-1963}

Idea zprůmyslněné typizované výstavby bytových domů, která dominuje poválečné produkci státního socialismu, vyžadovala permanentní výzkum nových technologií, materiálů, výrobních postupů a bytového vybavení. U nás se novým konstrukčním systémům, prefabrikaci a typizaci věnoval po roce 1948 například Studijní a typizační ústav, Ústav pro zprůmyslnění výstavby, Výzkumný ústav stavební výroby, Ústav bytové a oděvní kultury a řada dalších. Na vývoji se samostatně podílely také některé projektové a realizační ústavy (Stavoprojekty, Průmstav, Pozemní stavby).

K rychlému zprůmyslnění stavebnictví přispěly první poválečné směrnice obytného standardu, rozměrové moduly vybraných prvků a typové podklady (typy T 11-T 20) $\mathrm{z}$ roku 1951. Samostatnou linii pak sledovaly rané experimenty panelových domů v Gottwaldově (typ G 32, G 40) z počátku padesátých let, slovenský prototyp paneláku (typ BA) a vývoj skeletových konstrukcí s cihelnou či panelovou výplní (typy Wimmer nebo Janů). ${ }^{18}$

${ }^{15}$ Hugo Palmarola - Pedro Ignacio Alonso, Tropical Assemblage. The Soviet Large Panel in Cuba, in: Beyond Imported Magic. Essays on Science, Technology and Society in Latin America, Cambridge, Mass. 2014, s. 159-179.

16 Ibidem, s. 162. - Podobně se k historii panelové výstavby na svém území vyjadřují také estonští badatelé. Viz Constructed Happines. Domestic Enviroment in the Cold War Era, Tallinn 2005.

17 Více např. Virag Molnar, In Search of the Ideal Socialist Home in Post-Stalinist Hungary: Prefabricated Mass Housing or Do-It-Yourself Home?, Journal of Design History XXIII, 2010, No. 1, p. 61-81. Béla Kerékgyártó, Was Humanized Socialist Modernism Possible After All? The promise and Failure of Mass Housing in Hungary, in: Ákos Moravánszky - Judith Hopfengärter, Re-Humanizing Architecture: New Forms of Community, 1950-1970, Vol. I, Basel 2017, s. 63-84.

18 Prototyp kombinující vnitřní skelet s kvádrovým zdivem od Karla Janů z roku 1953 najdeme v Otrokovicích a ověřovací sérii pak v Praze na Ruské třídě. Prototyp Miloslava Wimmera byl dokončen v roce 1955 v Praze-Ďáblicích v ulici U Prefy a obdobný systém se použil i na jiných staveništích v Praze (Dejvice, Zahradní Město). Více např. Stanislav Hermann, Stavíme v Praze první montované domy, Nová Praha 1954, č. 25-26, s. 405. - Karel Janů, K otázce montovaných bytových staveb, Architektura ČSR XIII, 1954, s. 35-41. - Erich Kohn, Architektura montovaných bytových staveb, Architektura 
V polovině padesátých let se na první generaci celomontovaných panelových domů shlíželo s nedůvěrou. Technologie typů $\mathrm{G} 40$ a $\mathrm{G} 55$ byla tě̌̌kopádná, panelové prefabrikáty vyžadovaly náročnou výrobu, nákladný převoz prefabrikátů z paneláren i náročnou montáž objemnými portálovými jeřáby na kolejích [obr. 2]. Panelové domy neměly ani dostatečně vyřešenou tepelnou či střešní izolaci, ani vhodné omítky a tmely, na jejichž vývoji se ostatně pracovalo až do osmdesátých let. Svým vzhledem navíc první paneláky připomínaly krabice bez jakékoliv tvarové pestrosti, působily uniformně, stroze, až kasárensky. Vzhledově konzervativnější a přívětivější experimenty z prefabrikovaných cihlových kvádrů a montovaných skeletů panelákům konkurovaly. Zaváděly podobně rychlé a efektivní technologie a montážní postupy, ale "prri zachování dosavadní surovinové základny, a to bez velkých a riskantních investic". ${ }^{19}$ Nicméně i u nich se od druhé poloviny padesátých let předpokládal přechod na „efektivněǰ̌i “ výplně z panelů.

$\mathrm{Na}$ konci padesátých let sloužily experimenty jako odrazové můstky pro kvantitativně i kvalitativně náročnou bytovou výstavbu budoucího desetiletí. Směrnice Ústředního výboru KSČ „k ř řšení bytového problému“ $\mathrm{z}$ března 1959 stanovila termín realizace a centrálního vyhodnocení všech experimentálních staveb do roku 1961. Do omezené skupiny oficiálních experimentů se přijímala pochopitelně ta pracoviště, která byla s dosavadním výzkumem konstrukcí a s př́pravou projektů nejdál. A bylo z čeho vybírat.

Celomontovaný systém v té době patřil mezi protekční technologie, už díky „bratrským vzorům "v SSSR, ale architekti u nás současně rozvíjeli také monolitické soustavy, skelety a takzvanou „typizaci in situ“. Tyto metody převažovaly mezi experimentálními projekty studijního úkolu „Bydlení, který už v roce 1958 vyhlásil Svaz architektů ČSR a na němž pracovali hlavně architekti a konstruktéři, mezi nimi Miroslav Vejl, Vladimír Syrovátko, Miloslav Tryzna nebo Štefan Svetko. ${ }^{20}$ V letech $1958-1959$ pak probíhala prověrka stávajících projektů v krajích, a to jak platných typů (T 16, T 17, T 01-03 B, G 40) a jejich připravovaných alternativ, tak i soutěžních projektů a prototypů nových konstrukcí. Výzkumný ústav výstavby a architektury hned v březnu 1959 otiskl v Architektuře ČSR základní vyhodnocení těchto návrhů a vzájemné srovnání jejich technicko-hospodárských ukazatelu․ Mezi 29 př́klady najdeme projekty Výzkumného ústavu stavební výroby v Praze (autor Václav Havránek) a ve Zlíně (G 59, autor Bohumír Kula), Ústavu pro zprůmyslnění stavebnictví v Praze (autoři Karel Janů, Miloslav Wimmer) i jeho zlínského pracoviště (autor Bohumír Kula - G 57, G 58), návrhy Státního typizačního ústavu v Praze (autor Lubor Marek) a dále typy a pokusné projekty krajských projektových ústavů v Brně (autor František Zounek), Praze (autoři Jan Benda, Jaroslav Pokorný), v Bratislavě (Alojz Daříček, Ilja Skoček), Ústí nad Labem (autoři Jiří Moravec, Miroslav Vejl), ve Zlíně (Arnošt Kubečka) a dva projekty architekta Josefa Havlíčka podané Státním ústavem pro rekonstrukci památek.

Státní výbor pro výstavbu ve spolupráci s ministerstvem stavebnictví a po dohodě s krajskými národními výbory rozhodl, pravděpodobně i na základě uvedené bilance, o realizaci experimentů krajských projektových ústavů v Praze, Českých Budějovicích, Brně, Gottwaldově, Hradci Králové a v Bratislavě. Na oficiálních experimentech pracoval

ČSR XIII, 1954, s. 52-54. - Miloslav Wimmer, Panelové domy s montovaným skeletem, Praha 1956. Ludevít Végh, Montované stavby, Praha 1959.

19 Vlastimil Cuhel, Kvádrová výstavba, Architektura ČSR XVI, 1957, č. 4-5, s. 164.

20 Kamil Gross, K študijnej úlohe „Bývanie“, Architektura ČSR XVIII, 1959, č. 1, s. 11-17. 
dále pražský Studijní a typizační ústav, který se zaměřil primárně na půdorysy nových bytů, řešil novou kategorizaci, vztahy funkcí jednotlivých místností a možnou proměnlivost dispozic.

Ministerstvo výstavby na začátku roku vyhodnotilo prvních dvanáct experimentálních bytových domů. Obydleny v té době byly jen objekty v Hradci Králové a v Gottwaldově. Realizovaly se i mnohé projekty ostatních ústavů, které však nespadaly pod podporu a dohled Ústředního výboru KSČ. ${ }^{21}$

Nutno přiznat, že experimenty i vzhledem k šibeničnímu termínu probíhaly dost živelně. Kvůli shora stanoveným kritériím autoři často ověřovali přiliš mnoho věcí zároveň (konstrukce, materiály, dispozice) a negativní výsledky některých detailů pak zcela zastínily ty pozitivní. Objemové kubatury, ekonomické bilance a hodnoty pracnosti jednotlivých staveb nešlo vzhledem k odlišným okolnostem realizace (dodavatelé, jakost surovin) rozumně porovnat. Navíc novátorské postupy logicky nedosahovaly napoprvé nejlepších výsledků, většina $\mathrm{z}$ nich se teprve neobratně zkoušela. Architekt Julius Šif to popsal výstižně: „To jako bychom pokusnému králíkovi píchli najednou injekci spály, záškrtu a žloutenky, a pak se dohadovali, proč vlastně pošel. "22 Když k tomu připočteme ještě omezené možnosti výrobních podniků, pak ani při sebevětší politické protekci nemohly experimentálky dopadnout hned napoprvé ideálně. Některé parametry jejich výsledků nakonec neodpovídaly ani současně vydané Směrnici o rozměrové unifikaci (ČSN 730006), která výrazně redukovala moduly rozponů. ${ }^{23}$

\section{Experiment „na místě"}

Podívejme se nyní na jednotlivé experimentální stavby podrobně. Většina z nich ověřovala monolitické konstrukce nebo je kombinovala s montáží z předvyrobených panelů. ${ }^{24}$ Naprostá většina architektů preferovala výrobu panelů odléváním do svislých baterií přímo na místě. ${ }^{25}$ Tato metoda, stejně jako samotný monolit, umožnila nezávislost na omezeném sortimentu tehdejších paneláren. Oba postupy slibovaly větší tvưrčí možnosti, svobodu, práci s místním materiálem. Lze je označit za konstrukce ryze regionální, v podstatě decentralizované, nezávislé na jednotné „materiálně-technické základne“ státu.

${ }^{21}$ Experimenty s konstrukčním, architektonickým i dispozičním řešením zaznamenáme $\mathrm{v}$ letech 1959-1961 také v Ústí nad Labem (Hrnčířská, Josef Liška a Rudolf Bergr) či v Teplicích. V pozoruhodném plzeňském experimentu (PL 60) vycházel Karel Janů ze svého soutěžního projektu na bydlení budoucnosti (po roce 1970) v Moskvě. Experimentálních staveb vzniklo pravděpodobně mnohem víc, jejich seznam zatím není kompletní.

22 Julius Šif, Architekti experimentují, Domov II, 1961, č. 1, s. 8.

23 Markéta Žáčková, Od „nearchitektury“ $k$ experimentu. Nástup panelové bytové výstavby v Brně mezi lety 1955-1960, in: Rostislav Koryčánek (ed.), Na prahu zítřka. Brněnská architektura a vizuální kultura v období socialismu, Brno 2014, s. 214.

${ }^{24}$ Konstrukce byly založené na krabicovém prřčném nosném systému a různých délkách rozponů. Termín krabicový systém se používal hlavně v padesátých a šedesátých letech, v následující dekádě z terminologie mizí. Odkazuje s největší pravděpodobností na statický princip ztužení konstrukce po finálním zalití spojů stěn a stropů, čímž vniká jakási staticky ztužená krabice. Zahrnuje libovolně př́ičný i podélný nosný systém. Za konzultaci děkuji Michaele Janečkové.

25 Roman Pochop, Několik poznámek k řešení pokusných bytových domů v Praze, Hradci Králové a Brně, Architektura ČSSR XIX, 1960, s. 521. 
Zajímavé a progresivní projekty vznikaly v místech, kde architekti měli dobré osobní vztahy se stavebními podniky, nebo v místech s proaktivními funkcionáři okresního či krajského výboru KSČ. Sepětí architektů, inženýrů a technologů, společnou fascinaci technickým a vědeckým pokrokem lze vycítit i z popisů experimentálních staveb v časopise Pozemní stavby vydávaném ministerstvem stavebnictví. Domnívám se, že právě v pokusných stavbách si autoři osahali výhody otevřených stavebnicových systémů a „vůli ke změně. Ta je spolu s rostoucí společenskou pozicí, profesní i osobní ctižádostí architekta provázela během celých šedesátých let.

Výrobu panelů na staveništi, nazývanou tehdy ambulantní, využili téměř všichni autoři experimentálek. Většina $\mathrm{z}$ nich ji kombinovala s monolitickými konstrukcemi, tedy odléváním stěn anebo stropů do bednění. Taková metoda otevírala nebývalé možnosti v tvarování bytového domu, $\mathrm{v}$ jeho libovolné orientaci, výšce a uspořádání vnitřních dispozic. Do budoucna slibovala vysoké estetické kvality a flexibilitu v přechodu na ještě progresivnější technologie a materiály.

Ambulantní výroba panelů se v šedesátých letech rozšiřovala i mimo experimentální proud. ${ }^{26}$ Pozoruhodných výsledků s ní dosáhli architekti v Liberci. Poprvé ji zde v roce 1959 použil Jaromír Vacek ve spolupráci s Otou Nikodýmem při stavbě věžových domů na sídlišti Králův Háj [obr. 3]. ${ }^{27}$ Vacek si zde vyzkoušel volnější způsob práce s typizovanými prvky tak, aby obytnému domu vtiskl individuální architektonický výraz a pestřejší dispozice. O devět let později tuto „tradiční libereckou technologii“ Vacek dovedl do dokonalosti v projektu bytového domu Wolkerova (Jaromír Vacek, Václav Voda, realizace 1968-1972) [obr. 4]. Mohutný obytný dům, do oblouku zakousnutý do úbočí Jizerských hor, patři mezi jedinečné ukázky architektonických představ kvalitního bydlení konce šedesátých let. Naznačuje, že práce s typizovanými prvky nemusela nutně vést $\mathrm{k}$ monotónním a bezduchým shlukům krabic a že i panelák mưže být opravdu krásný. ${ }^{28}$

Možnosti ambulantní výroby neboli staveništní prefabrikace mohli architekti sledovat především na Západě, v Anglii a ve Skandinávii. V oficiální zprávě pro Komisi ÚV KSČ pro řešení bytového problému se píše, že ke staveništní prefabrikaci se v západních zemích přiklánějí i z toho důvodu, že výroba prefabrikátů ve stálých výrobnách (vzdálených do 40-50 kilometrů) se vyplatí až od výstavby sídlišst nad 4500 bytů. ${ }^{29}$

$\mathrm{Z}$ experimentálních staveb budu v následujícím textu věnovat pozornost především monolitům a jejich tvarovému i architektonickému výrazu. Představím také domácí i zahraniční příklady rozvíjející danou konstrukci v šedesátých a sedmdesátých letech.

26 Ambulantní výrobu panelů v roce 1959 plně podpořilo také ministerstvo stavebnictví. Ministr Oldřich Beran ve zprávě uvádí klady ambulantních výroben - využívání místních surovin, výroba většího sortimentu stavebních dílů a to vše při téměř stejné efektivitě jako v panelárnách. NA 10/22, Komise ÚV KSČ pro řešení bytového problému, sv. 1, aj. 2, zasedání ze dne 25. 6. 1959, bod 4, Návrh možnosti zř́izení ambulantních výroben stavebních hmota a konstrukcí, fol. 2-6.

27 Více viz Eva Novotná, Králův Háj, in: Lucie Skř̌ivánková - Rostislav Švácha - Eva Novotná - Karolina Jirkalová (eds), Paneláci 1. Padesát sídlišt v českých zemích. Kritický katalog k cyklu výstav Př́běh paneláku, Uměleckoprůmyslové museum v Praze 2016, s. 172-179.

28 Více viz Eva Novotná, Obytný soubor Wolkerova, in: Skřivánková - Švácha - Novotná - Jirkalová (eds), Paneláci 1 (pozn. 27), s. 270-275.

29 NA, fond KSČ-ÚV-K 1945-1989, Komise pro řešení bytového problému 10/22, sv. 4, a. j, 18, zasedání 29. 12. 1961, bod 6: Informativní zpráva pro komisi politického byra ÚV KSČ pro řešení bytového problému o zkušenostech z pokrokové bytové výstavby v zahraničí, fol. 1-17. Pro srovnání uvádím, že takové velikosti dosahovalo u nás $\mathrm{v}$ šedesátých letech například brněnské sídliště Lesná, které počítalo přibližně se 6000 byty. 


\section{Monolity}

Jeden z prvních experimentálních bytových domů oveř̌ujících výhody monolitické konstrukce vyrostl v letech 1958-1959 v Praze-Bubenči v ulici Ve Struhách [obr. 5]. ${ }^{30}$ Jeho autoři Václav Havránek a Miroslav Rủžička spolu s Výzkumným ústavem stavební výroby navrhli monolitický krabicový systém, ve kterém obvodová litá stěna může i nemusí př̌ebírat váhu konstrukce. Experiment samozřejmě cílil na snížení ceny, která se měla pohybovat dokonce kolem 45000 Kč za byt (ceník nákladů, jak už bylo řečeno, tehdy počítal s 58-64 000 Kčs na byt). Výhodou pokusné stavby byla také její nízká váha a pracnost odpovídající v podstatě montáži z panelů. Povrchy se díky bednění $\mathrm{z}$ opracovaných a vodě odolných překližek nemusely omítat, jen se štukovaly a natíraly. Největší výhoda, jak zdůraznili i autoři, však spočívala v tom, že monolitické konstrukce se mohlo použít nezávisle na dodávkách paneláren a bez potřeby jeřábu, tedy i ve svažitých terénech. ${ }^{31}$ Volná vnitřní dispozice umožňovala variabilní přepažení lehkými dřevěnými př́čkami s povrchem z omyvatelných, lakovaných či tapetovaných překližek. Absolutní uvolnění vnitřní dispozice bytů s flexibilní možností přepažení patř́ $\mathrm{k}$ jednomu $\mathrm{z}$ hlavních poznatků experimentů vůbec.

V Brně na Vinařské ulici se ve stejné době postavil podle projektu Františka Zounka a Viktora Rudiše pokusný bytový dům s monolitickou konstrukcí (1959-1960). ${ }^{32}$ „Litý beton dopadl výtečně, tedy hlavně z pohledu spotřeby materiálu. Pan Erich Kohn, ředitel Typizačního ústavu, se prímo nadchl, a tak jsem stavěl další experiment s litým betonem, tentokrát desetipatrový, naproti Rondu. " ${ }^{33}$ Tak vzpomínal Zounek na své experimenty z konce padesátých let. Na projektu jedenáctipodlažního domu „naproti Rondu“, na Kř́́dlovické ulici, spolupracoval s Milanem Pospíšilem (1958-1961) a použil zde prŕíčný nosný systém odlévaných stěn i stropů $\mathrm{v}$ kombinaci s lehkou zavěšenou obvodovou stěnou [obr. 6]. ${ }^{34} \mathrm{~V}$ dispozici pak autoři vyzkoušeli půlkruhové schodiště, vnitřní uměle větranou kuchyň a některé další detaily, třeba rozvod elektřiny, který si každý nájemník provedl dodatečně sám..$^{35}$

Na první pohled věžák na Kř́dlovické ulici zaujal dobovou kritiku výraznou modernistickou kompozicí průčelí. Julius Šif tehdy napsal: „To už nebyla fasáda obytného domu, ale jakási odhmotnèná podivná stavebnice různých skleněných a laminátových ploch oken, obkladů, zábradlí, lodžií - vyzařujicí ostré paprsky, jakýsi průsvitný neskutečný křiš-

30 Na obdobných projektech v té době pracovali v Ostravě, Ústí nad Labem a v Bratislavě. Více Václav Havránek - Miroslav Růžička, Monolitický krabicový obytný dům, Pozemní stavby VI, 1958, č. 10, s. 515-521.

31 Ibidem, s. 515. Za nouzový př́pad použití monolitu bych si dovolila označit i trojici pokusných bytových domů $\mathrm{z}$ litého betonu $\mathrm{v}$ Jihlavě na sídlišti č. II z počátku šedesátých let. Za upozornění na tento experiment děkuji Janě Koř́nkové, která mi laskavě poskytla také jeho podklady a fotografii.

32 Oba projekty na pokusné domy v Brně vzešly z interní soutěže brněnského Stavoprojektu. Karel Storch, Pokusný bytový dům o 11 podlažích v Brně, Architektura ČSSR XX, 1961, č. 5, s. 307-314.

33 Záznam rozhovoru s Františkem Zounkem a Viktorem Rudišem (Eva Novotná, 16. 4. 2004).

34 Více viz Karel Storch, Pokusné stavby, prototypy, projekty a studie rozvíjející novou techniku, Architektura ČSSR XX, 1961, č. 5, s. 305. - Dušan Riedl - Bohumil Samek, Moderní architektura v Brně 1900-1965, Brno 1967, s. 115.

35 Více viz Jindřich Chatrný, Experimenty z cihel a betonu v Brně na nábřeží řeky Svratky, Brno v minulosti a dnes, č. 28, 2015, s. 393-423. 
tálový palác, sen, snad vize architektury budoucna. "36 Zvlášt aktuálně vyznívají slova téhož autora, který zpochybňuje trvanlivost materiálů a tím i účinek takové architektury: „Jde totiž o to, aby nová stavba za několik let nevybledla', aby kouzlo nové architektury nebylo príliš krátkodobé. Ve srovnání pak zřejmě lépe obstál „klasický“ tektonický rastr průčelí Havránkova experimentu v Praze-Bubenči, ale i ten nedávno znetvořilo zateplení, podobně jako u věžového domu na Křídlovické ulici v Brně.

Brněnské experimenty vzbudily velký zájem a značnou publicitu. Vzorově vybavený byt na Kř́idlovické se otevřel formou výstavy široké veřejnosti a zapojil se tak spolu s ostatními vzorovými byty v krajských experimentech do již zmiňované celostátní diskuse o bydlení, respektive do její druhé fáze. I když brněnské pokusy nepřešly, podobně jako ostatní monolity, do typového provedení, ve městě se podle takzvaného „typu Zounek“ postavilo družstevně ještě několik dalších bytových domů. ${ }^{37}$ Dodejme, že vedle věžového domu na Křídlovické se současně postavil ještě experiment čtyřpatrového domu z keramických tvárnic (Radko Černý, Miroslav Brabec, Miroslav Pospíšil, 1958-1959) a soubor brzy doplnila stavba jeslí.

Také v Teplicích se v letech 1958-1961 zkoušela monolitická konstrukce, konkrétně krabicový systém odlévaný do posuvného bednění. ${ }^{38}$ Zvolenou technologií, zejména zpưsobem bednění, navazovali autoři Jiří Moravec a Jaromír Vejl na obdobné experimenty na Slovensku. Podél ulice Duchcovská nakonec stojí trojice těchto zajímavých sedmipatrových domů s výrazně tvarovanou střešní nástavbou v bruselském stylu. ${ }^{39}$ Kromě výtahové strojovny do ní autoři chtěli umístit také společné prostory s př́stupem na střešní terasu. Teplický experiment opakuje př́jemný kompoziční rastr fasád, jaký najdeme i na experimentu v Praze-Bubenči nebo na domech typu BA v Bratislavě. V Teplicích si architekti pochvalují, že „dosavadní vývoj práce jasně ukazuje, že postupně nabývané zkušenosti umožní dalši rozmanitost a náročnost v řešení průčelí. 40

\section{Bratislavský experiment}

Po kapitole o monolitech si dovolím krátkou odbočku ke slovenským experimentům z konce padesátých let. Slovenské bytové výstavbě dominovala bratislavská panelová konstrukční soustava BA, která byla konstrukčně i architektonicky velmi pozoruhodná. Za prototypem montovaného domu BA, takzvaného typu „MONTDOM“, stál v letech 1952-1953 Vladimír Karfík (spolupráce Georgi Turzunov, Jozef Harvančík a Karel Šafránek). První panelový dům tohoto typu byl dokončen v roce 1955 na Kmetově náměstí

36 Julius Šif, Poznámky o některých kompozičních otázkách a o výtvarném řešení obytných budov, Architektura ČSSR XX, 1961, s. 260.

37 Více viz Markéta Žáčková (pozn. 23), s. 209-217. - Markéta Žáčková, „Byl sice jistý plán...“Výzkumný ústav výstavby a architektury a experimentální bytová výstavba přelomu padesátých a šedesátých let 20. století, Sešit pro umění, teorii a príbuzné zóny VVP VIII, 2014, č. 17, s. 20-49.

38 Jiří Moravec, Jaromír Vejl, Projekt osmipodlažních obytných domů v Teplicích, Pozemní stavby VII, 1959, č. 2, s. 139-144.

39 Více např. Osmipodlažní obytný dům v Teplicích, Architektura ČSSR XX, 1961, s. 321-322. - Jana Zajoncová, Otázka komplexní bytové výstavby v Teplicích aneb Jak překonat „zkostnatělé řeholní pojetí socialismu... “, in: Jan Hanzlík - Jana Zajoncová - Lenka Hájková, Teplice: Architektura moderní doby 1860-2000, Ústí nad Labem 2016, s. 226-228.

40 Jiří Moravec, Jaromír Vejl (pozn. 38), s. 142. 
v Bratislavě a od roku 1958 se typ BA používal na Slovensku sériově. Na rozdíl od typů G používal systém BA předepjatých rámů s keramzitbetonovou výplní. Kombinace předepjatého betonu a keramzitu zaručovala výraznou pevnost a zároveň lehkost konstrukce. ${ }^{41}$ Systém vynikal také dobrou dispoziční skladebností danou jednoduchým čtvercovým modulem stropních panelů $(375 \times 375 \mathrm{~cm})$. Na přelomu padesátých a šedesátých let se systém BA v Bratislavě velmi rozšíril a postupně se vyvíjela i jeho technologie. Působivých výsledků dosáhl v kombinaci s monolitickým přízemím, kam architekti umistovali obchody a služby. ${ }^{42}$

Nápaditou architekturu bytových domů BA, včetně oživeného parteru, můžeme vidět na sídlišti Škultétyho-Kukučínova (Georgi Turzunov a kolektiv, 1956-1960). Ve stejné době se v Bratislavě staví sídliště Februárového vítazstva (Štefan Svetko, Ondrej Dukát, Václav Houdek, Štefan Ďurkovič a kolektiv, 1953-1961), na kterém se zkoušel i první experiment $s$ konstrukcí z litého betonu (systém LB). Vysoké monolity dopadly výborně a sídliště Februárka dodnes poutá pozornost kvalitní architekturou deskových a věžových domů rozmístěných v pravoúhlém rastru uprostřed zeleně [obr. 7]. Architekti zde věnovali pozornost komplexní občanské vybavenosti obytného okrsku, hierarchii veřejného a poloveřejného prostoru, zeleni i umělecké výzdobě. Autoři bratislavského Atlasu sídlisk po právu označují Februárku za nejlepší sídliště šedesátých let na Slovensku. ${ }^{43} \mathrm{Na}$ kvalitě projektu se jistě podepsala i zkušenost autorů z mezinárodní soutěže na obytný obvod jihozápadní části Moskvy. Ostatně mezi účastníky moskevského klání najdeme také další jména architektů experimentálních staveb - Václava Havránka, Františka Zounka, Viktora Rudiše či Bohumíra Kulu.

Na začátku šedesátých let vznikl v Bratislavě experimentální obytný okrsek Krasňany. Ověřoval celkem pět typů bytových domů. Autoři zde vyzkoušeli a vzájemně porovnávali montované konstrukce s litým a vakuovaným betonem a konstrukce s menšími tvárnicemi z pórobetonu a s velkorozměrnými prvky z plynobetonu. Výzkumný ústav výstavby a architektury toto sídliště v roce 1961 na poslední chvíli zařadil mezi centrálně sledované experimenty. ${ }^{44}$ Právě výsledky použitých pórobetonů zaujaly hodnotitele nejvíc. Komise pro řešení bytového problému při ÚV KSČ nakonec doporučovala pro př́ipravu dalších typových podkladů využít kromě pórobetonů také velkorozponové šestimetrové konstrukce z celomontovaných experimentů v Hradci Králové (HK 60) a v Praze na Invalidovně. ${ }^{45}$

Technologie lehčených betonových prefabrikátů - tzv. pórobetonů, též podle druhu pojiva plynosilikátů a plynobetonů - se v té době hodně používala ve Švédsku, v Dánsku a v Sovětském svazu. Na Slovensku se začaly zkoušet už v roce 1958 a od roku 1963 se zde licenčně vyráběl švédský konstrukční systém (SIPOREX). Princip jejich výroby tkví

41 Georgij Turzunov, Obytný dom z predpätých panelov typu BA v Bratislave, Architektura ČSR XVI, 1957, s. 179. - Sídlisko panelov BA, Přehlídka prací za rok 1957, Architektura ČSR XVII, 1958, s. 264-265.

42 Více např. Michal Čech, Vývoj komplexnej kvality panelových domov, Pozemní stavby XII, 1964, č. 7, s. $276-281$.

43 Henrieta Moravčíková - Peter Szálay a kol., Bratislava - Atlas sídlisk, Bratislava 2011.

${ }_{44}$ Michal Čech, Skúsenosti z výstavby experimentálního sídliska v Krasňanoch, Pozemní stavby XII, 1964, č. 7, s. 296-298.

45 NA, fond KSČ-ÚV-K 1945-1989, Komise pro řešení bytového problému 10/22, sv. 4, a. j. 17, zasedání 20. 11. 1961, bod 4: Zajištění bytové výstavby podle nových typových podkladů od roku 1963, s. 8 . 
v lehčení betonových prefabrikátů pomocí chemické reakce. Kvůli výhodám plynosilikátů a plynobetonů ministerstvo výstavby v šedesátých letech opakovaně tlačilo na větší „chemizaci“ stavebnictví.

\section{Poučení z monolitu}

S monolitickými konstrukcemi měli na přelomu padesátých a šedesátých let nejlepší zkušenosti stavbaři ve Švédsku. Skandinávské a zejména švédské stavebnictví čeští experti i pracovníci ministerstva stavebnictví trvale sledovali. Časopis Pozemní stavby otiskl již v roce 1958 poznatky ze společné cesty zástupců Státního výboru pro výstavbu a Výzkumného ústavu výstavby a architektury do Norska, Švédska a Dánska. Velkou pozornost skupina věnovala technologii posuvného bednění, kterou Švédové využívali pro nosné konstrukce a u výškových domů pro tažení schodištové věže, ze které pak pomocí jeřábu osazovali zbylé konstrukční prvky či závěsné stěny. ${ }^{46}$ Monolitické konstrukce autor článku z pozice Státního výboru pro výstavbu důrazně doporučuje vyzkoušet i v naší bytové výstavbě. O několik čísel později informuje v témže časopise o monolitických konstrukcích Miroslav Olexa. Zmiňuje připravovaný Havránkův experiment v Praze-Bubenči a porovnává v této souvislosti naše bednící materiály s dokonalejšími švédskými. ${ }^{47}$ Švédové v šedesátých letech pravidelně vystavovali také na brněnských veletrzích, kde novinky ve způsobu bednění budily pozornost českých expertů.

Monolitické konstrukce, které přece jen vyžadovaly větší přesnost při realizaci, nakonec v šedesátých letech našly své místo i u nás, zvláště v prrípadě vysokých bytovek. Poměrně často se však objevují v kombinaci s prefabrikáty, jako např́klad ve zmiňovaném zlínském či bratislavském experimentu nebo v pozdějším „krásném“ sídlišti v Praze-Ďáblicích [26]. Ostravská krajská varianta pro stavbu výškových domů (V-OS 64) kombinovala montovanou konstrukci s taženým železobetonovým jádrem.

To, že s pomocí monolitické konstrukce lze stavět pestřejší a architektonicky kvalitnější bytové domy, potvrdili také autoři půvabného libereckého sídliště při ulicích Aloisina výšina a Franklinova (Vladimír Syrovátko, Jiří Hubka, realizace 1976-1981). ${ }^{48}$ K dispozici zde již měli západoněmeckou licenci systémového (víceobrátkového) bednění, kterou na konci šedesátých let zakoupil slovenský podnik Inženierského stavitelstva (systém IS NOE COMBI).

Ojedinělý experiment s monolitickou konstrukcí pak představuje hotelový dům na sídlišti Šanov II v Teplicích od architekta Miroslava Masáka (projekt 1965, realizace 1972-1978). Použití monolitické, tažené schodištové věže a následného „osazování pater prrímo z věže připravoval Masák s týmem konstruktérů od roku $1968 .{ }^{49}$ Využili při

46 Oldřich Strádal, Bytová výstavba ve Skandinávii, Pozemní stavby VI, 1958, č. 5, s. 266-271.

47 Vylepšená hladká bednění o velikosti celých stěn umožňovala hlavně co nejhladší povrch betonu bez spár, který se pak nemusel omítat, ale jen se natíral nebo stříkal. Více Miroslav Olexa, Vyšší obytné domy s monolitickou konstrukcí, Pozemní stavby VI, 1958, č. 11, s. 565-569.

48 Studie Franklinova, Státní okresní archiv Liberec, fond Městského národního výboru, inv. č. 466, 468, 469.

49 Závěrečná zpráva o průběhu experimentálního ověřování objektu hotelového bydlení v sídlišti Teplice-Šanov II, prosinec 1969, s. 1-9. Archiv Stavebního úřadu Teplice, inv. č. 1516/2. 
tom zkušeností Sialu s obdobnou konstrukcí souběžného projektu televizního vysílače na Ještědu. ${ }^{50}$

\section{Panelák jako nástroj centralizace}

Základním smyslem experimentů podle Ústředního výboru KSČ bylo směřovat bytovou výstavbu k neúprosnému zprůmyslnění, to znamená co nejúčinněji rozvíjet typizaci a průběžnou unifikaci stavebních dílů - zejména betonových panelů a celých výrobních a stavebních procesů. Veškerá práce na staveništi měla důsledně přejít na proudovou metodu založenou na koordinaci pracovních čet, které podle specializace postupují v daném harmonogramu po jednotlivých stavbách nebo dokonce okrscích a celých rajónech. Prefabrikáty a konstrukční prvky měly minimalizovat dokončovací práce - panely se vyráběly včetně okenních rámů, venkovních omítek a obkladů. Nově používaná smontovaná bytová jádra takzvaného skř́ínového typu sledovala stejné cíle.

$\mathrm{V}$ archivních materiálech $\mathrm{k}$ výsledkům experimentů zcela chybí kritický pohled hodnotitelů nebo argumentace samotných tvůrců pokusných staveb. Srovnání ekonomických i technických ukazatelů působí nejednoznačně. Nelze z nich vyčíst, proč se ve výsledku vybraly jako „nejlepši“ celostěnové konstrukce z panelů. Nabízí se ovšem i vysvětlení, že v Sovětském svazu protežovaný panelák se v době Nikity Chrušova těšil i v ostatních satelitních zemích „socialistického tábora“ čistě politické protekci. Navíc jeho koncentrovaná výroba v plánovitě rozmístěných panelárnách nabízela jednoduché a univerzalistické řešení, ke kterým státní socialismus tíhnul. Taková výroba se z centra také lépe řídí a kontroluje.

Ekonomická kalkulace vycházela na konci padesátých let dokonce lépe pro cihelné domy než pro domy z panelu. Bylo to dáno momentální cenovou politikou a vysokou odbytovou cenou panelů. Jak bytová družstva, tak i většina krajských národních výborů ještě na začátku šedesátých let odmítaly stavět panelové domy, protože jsou příliš drahé. Nasnadě bylo politicky protlačit panelové domy cenovou regulací shora. „Prosil bych, aby politické byro i vláda rozhodly otázku cen panelové výstavby. Družstevníci nám ani v jednom př́padě na ni nesáhli. Je to výstavba drahá. Nečekat se zlevněním této výstavby až do roku 1961, ale pomoci, aby byly panelárny využity již v roce 1960 pro družstevní a podnikovou výstavbu. " ${ }^{1}$ Taková slova zazněla např́iklad na celostátní poradě krajských výborů v roce 1959, kde si delegáti na vysokou cenu stěžovali. Nabízela se i možnost panelovou výstavbu finančně zvýhodnit formou prémií: „Lidé, kteři montují rychlostavbu, jsou materiálně zainteresovaní, mají prémie na celou stavební správu. (...) Je možnost říci, dokud soudruhu řediteli nebudeš panelové domy stavět tímto zpusobem, bude to mit vliv na tvou materiální zainteresovanost. (...) Když se v celé republice rodí panelové hnutí, nesmíme to

50 Jana Zajoncová, Teplice, Šanov II, in: Skřivánková - Švácha - Novotná - Jirkalová (eds), Paneláci 1 (pozn. 27), s. 276-281. Rané prríklady obdobné technologie jsem zmiňovala také v souvislosti se zkušenostmi z výstavby sídlišt ve Švédsku.

51 NA, fond KSČ-ÚV-K 1945-1989, Komise pro řešení bytového problému 10/22, sv. 1, a. j. 5, zasedání 16. 11. 1959, bod 1: Celostátní porada předsedů komisí KV KSČ a pracovníků KV KSČ z úseku stavebnictví pořádaná XI. oddělením ÚV KSČ 30. 10. 1959, fol. 85. 
utopit tím, že tomu dáme od počátku špatnou organizaci. “52 Cena panelových prefabrikátů se nakonec snížila po roce 1962 novou regulací cen.

Celomontovanou konstrukci z panelu ověřovali v experimentech nejprve jen architekti Krajského projektového ústavu v Hradci Králové, František Steiner a Jaroslav Škaloud. "Je to velmi dobrý a radostný príklad dobré spolupráce techniků a dělníkư,"53 komentoval tehdy jeho stavbu delegát celostátní porady z Hradce Králové [obr. 8]. Zmínil, že stavba bude hotová už na konci roku 1959 a budou v ní bydlet ti, co ji projektovali a vyráběli, „aby vyzkoušeli tento di̊m na vlastní kưži“. Pokusné domy s nezvykle dlouhým rozponem 6,2 metrů, postavené na Slezském Předměstí, předurčily vývoj později velmi rozšířeného krajského typu HK 60 a HK 65, ze kterého vycházel částečně i celostátním typ T 08 B. ${ }^{54}$ Zásadní vliv na prrípravu celostátních typů pak měl experiment s celomontovanými konstrukcemi v Praze na Invalidovně, který vyzkoušel i jejich průběžnou unifikaci napříč celým obytným okrskem (Jiří Novotný, Josef Polák, Vojtěch Šalda, Václav Havránek a kolektiv, 1960-1965) [29]. Příprava nových typů se ohlížela i na zkušenosti z bratislavských experimentů.

\section{Poučení z experimentů}

Výzkumný ústav výstavby a architektury a Komise pro řešení bytového problému při vyhodnocení experimentů sledovaly hlavně hledisko dobrých ekonomických výsledků ve snížení spotřeby hmot, váhy prefabrikátů, pracnosti stavby a zvýšení rychlosti hrubých i dokončovacích prací. ${ }^{55}$ Ve srovnání nejvíce sledovaného kritéria, hospodárnosti, mnohé pokusné stavby nedopadly zrovna nejlépe a jejich konstrukce a postupy byly hodnocené jako př́liš drahé. Jejich ekonomické výsledky ovšem ovlivňovala do značné míry cenová politika státu, která tvorbu cen, jak už jsem několikrát zmiňovala, nepřizpůsobovala realitě, ale centrálnímu plánu. „Zcela samostatnou kapitolou je vlastní zajištování realizace experimentálních staveb. Dosavadní praxe nenasvědčuje tomu, že by jejich výstavba byla pro všechny zúčastněné přitažlivou a př́ijemnou. (...) Byli bychom pro každoroční realizace experimentư, tím bude vyloučen charakter jednorázové akce, nedostatečně připravené a materiálově zajištěné. "56 Takto komentovali špatnou situaci ve stavebních dodávkách experimentů Bohumír Kula a autoři experimentálního sídliště v Praze na Invalidovně v diskusi pro časopis Architektura ČSSR.

Pokusné stavby se porovnávaly s rozšířenými, ale př́iliš uniformními panelovými typy $\mathrm{G}$ (hlavně G 57) a novějšími typy T $01 \mathrm{~B}-\mathrm{T} 03 \mathrm{~B}$, využívajícími cihelných prefabrikátů (kvádrů) nebo betonových tvárnic (blokopanelů). Z experimentů se nakonec další typo-

\footnotetext{
52 Ibidem, s. fol. 125.

3 Ibidem, fol. 102.

4 Pochop, Několik poznámek (pozn. 25), s. 520-527.

55 Státní výbor pro výstavbu stanovil konkrétní časové a finanční limity $(52000$ Kčs na byt $37 \mathrm{~m} 2$, realita se pohybovala kolem 60-64 000 Kčs). Výstavbu pokusných staveb měly financovat krajské výbory, náklady navíc vzešlé z nových pokusných materiálů, konstrukcí apod. měly hradit Státní výbor pro výstavbu a ministerstvo stavebnictví. Na jejich základě komise vydala pro 3. pětiletku Směrnici opatření pro rozvoj a modernizaci výroby a stavebních materiálů. NA, fond KSČ-ÚV-K 1945-1989, Komise pro řešení bytového problému 10/22, sv. 2, a. j. 9, zasedání 23. 5. 1960, Zpráva o komplexním vyhodnocení pokusných projektů bytové výstavby (Jiří Voženílek, Státní výbor pro výstavbu), s. 21.

56 Diskuse: K experimentálnímu projektování, Architektura ČSSR XIX, 1960, s. 559.
} 
vé podklady měly poučit jen velkým rozponem (6 metrů) a jeho kombinací s rozpony menšími, kterou ověrili autoři pražského sídliště Invalidovna. Největší dopad měly závěry $\mathrm{z}$ diskuse o bydlení podpořené názory odborníků $\mathrm{z}$ Výzkumného ústavu výstavby a architektury. Na jejich základě se zvýšil plošný standard bytu z 9 na $11 \mathrm{~m}^{2}$ na osobu a výrazně narostl podíl bytů vy̌ší kategorie, hlavně bytů $3+1$. Závazně tato kritéria pro novou výstavbu určila vláda usnesením z roku 1960. Komise dále doporučila přechodně pokračovat s typy řady $\mathrm{T}$ ( T 01-T 03 B) či s vylepšeným panelovým typem G 57 (krajské varianty B 60, G-OS, G 57-OL). Brněnskou variantu domu G 57 (G 57/9 neboli B 60), připravovanou pro sídliště Lesná, uvítal na stránkách časopisu Architektura ČSSR Karel Prager, který si neodpustil poznámku, že v minulosti jsme si stavebně i urbanisticky špatnými domy typu $\mathrm{G}$ zvlášt uškodilii. ${ }^{57}$

V době vyhodnocování experimentů, kolem let 1961-1962, cítíme opět potřebu ústředních orgánů mít vše pod byrokratickou kontrolou, veškeré postupy koordinovat, urychlovat a na vše obezřetně dohlížet. Takové postoje ve výsledku kýžený pokrok brzdily. Výzkumným ústavům, podnikům a projektovým ústavům nedalo centrum potřebnou volnost $\mathrm{k}$ tomu, aby $\mathrm{v}$ experimentech zaměřených na bydlení dále pokračovaly. Zastavil se tak $\mathrm{v}$ podstatě vývoj konkurenčních a alternativních konstrukcí, které bohužel neměly možnost jít vlastní cestou úspěchu či neúspěchu. Podmínky experimentální výstavby navíc od roku 1962 podléhaly sjednoceným a přísnějším pravidlům.

Na politické a administrativní úrovni se v sérii experimentů odráží již zmiňovaná trajektorie reformních snah začátku šedesátých let: od centralizace $\mathrm{k}$ decentralizaci a zase zpět. Domnívám se, že velké množství i kvalita studií a experimentů, které se na začátku šedesátých let objevují, souvisely mimo jiné i se snahou o demokratizaci poměrů, decentralizaci a modernizaci státních podniků. Pro projektové ústavy a stavební podniky byla takovým impulsem „materiální zainteresovanost" na výzkumu daná vyhláškou Státní plánovací komise „o zvýšení hmotné zainteresovanosti na rozvoji a zavádèní nové techni$k y^{\text {“ }} .^{58}$ Vyhláška z následujícího roku pak stejným způsobem regulovala př́pravu nových typových podkladů. ${ }^{59}$ Projektantům slibovala vy̌šsí podíl prémií $\mathrm{v}$ př́ípadě, že $\mathrm{v}$ typech použijí nové technologie. Cíle „novátorstvi “ však vyhláška přesně diktovala: výrazně zlehčit stavbu, využít odpadového materiálu (popílku, strusky) a podobně. Decentralizace, přenesení zodpovědnosti na podniky a podpora inovací mohly otevř́i prostor pro zdravou podnikavost a aktivizovat architekty i stavební inženýry k zlepšení bydlení, pokud by ji však centrální orgány v podstatě okamžitě nenahradily zpětnou centralizací. Vyhláška č. 97/1962 sjednotila do budoucna podmínky, za kterých mohou experimenty vznikat, a zpř́ínila jejich financování i hodnocení. ${ }^{60}$ Vědecký a technický vývoj ve stavebnictví pak zcela centralizovala vyhláška č. 8/1963 „o financování neinvestičních nákladi̊ rozvoje vědy a techniky“. ${ }^{61}$ Vývojové projekty a experimenty zařadila pod hlavičku státních úkolů a pod kontrolu ústředních orgánů a Státní komise pro rozvoj a koordinaci vědy a techniky.

57 Karel Prager, Upravený panelový dům G 57, Architektura ČSSR XXI, 1962, č. 5, s. 295-297.

58 https://www.epravo.cz/vyhledavani-aspi/?Id=29609\&Section=1, vyhledáno 1. 11. 2017.

59 https://www.epravo.cz/vyhledavani-aspi/? Id=29915\&Section=1\&IdPara=1\&ParaC=2, vyhledáno 3. 11. 2017.

$60 \mathrm{https} / /$ /www.epravo.cz/top/zakony/sbirka-zakonu/vyhlaska-ministerstva-vystavby-o-dokumentaci -sledovani-a-vyhodnocovani-experimentalnich-staveb-6512.html vyhledáno 7. 11. 2017.

61 https://www.epravo.cz/vyhledavani-aspi/?Id=30387\&Section=1\&IdPara=1\&ParaC=2 vyhledáno 7. 11. 2017. 
V atmosféře optimismu druhé poloviny šedesátých let se však spontánně vzedmula druhá vlna experimentů. Modernistický étos pokroku a lidské emancipace vrcholil v technicistních utopiích domů-měst (Karel Honzík, Domurbie, 1962-1965) a v urbanistických megastrukturách velkoměstských satelitů (Gorazd Čelechovský a kolektiv, Etarea, 1967) ovlivněných futuristickými vizemi budoucí společnosti [obr. 9].

K nim přiřazují Rostislav Švácha a Ludmila Hájková také neoficiální experimenty mladé generace studentů architektury, kteří proti stereotypům modernismu vystoupili v roce 1967 na půdě ČVUT výstavou nazvanou Apelace. ${ }^{62}$ V otázce bydlení se z mladší generace architektů pokusil rozbít stereotyp bydlení např́iklad Stanislav Švec. Jeho projekt Slunečního města vystupuje proti silné poválečné tradici racionalizace sociálních funkcí architektury a úspornosti výroby. Zastupuje naopak zcela jiný typ experimentu ve smyslu jedinečné podoby bydlení, náročné na nejnovější technologie, konstrukce a inovace.

Nabízí se srovnání těchto experimentů se soudobým děním na Západě, kde se druhá generace experimentů podle Petra Cooka, člena britského Archigramu, také už neopájela samotnou výrobou a levnou prefabrikací jako experimenty z padesátých let, ale přinášela skutečně nový, převratný pohled na navrhování. Pojetí obytného domu se mělo přizpůsobit např́iklad rychle se měnícímu zpo̊sobu života, vkusu a rostoucímu konzumu. Dům se více, jak předvídal Cook, připodobní třeba automobilu či jinému př́istroji, který se také rychle proměňuje a přizpůsobuje člověku. ${ }^{63}$

V oficiální tvorbě sedmdesátých a osmdesátých let se u nás přestalo experimentovat téměř úplně. Př́ípravu a realizaci pokusných staveb ovlivňoval rostoucí počet vyhlášek a československých státních norem. Optimismus a chư stavebních podniků i architektů v bytové výstavbě něco měnit rapidně poklesla. ${ }^{64}$ Poptávka po experimentech se omezila na konstrukce určené pro výstavbu na poddolovaném území nebo na nižší energetickou náročnost bytových domů.

\section{Zrod sídliště}

„Ưčelná skladba několika druhů domů výrazně výškově odstupňovaných a vhodně barevně ř ̌̌sených, vystřídaných pásy zeleně, je nejúčinnějším a zároveň nejhospodárnějším architektonickým prostředkem pro vytvoření zdravého, kulturního a př́jemného obytného prostředí."65 (Jiří Voženílek, 1960)

Experimenty měly od počátku ověřovat výstavbu domů, které v budoucnu, respektive už po roce 1963, budou tvořit plně vybavená moderní sídliště pro 10-50 tisíc obyvatel. Zvláště jeden jejich druh, experimentální okrsky, proto ověřoval nejen nové konstrukce, ale i nový způsob života v prostorových celcích. Rozšiřoval dosavadní typologii bytových

62 Rostislav Švácha - Ludmila Hájková, Kde budeme žít zítra, in: Vít Havránek (ed.), Akce slovo pohyb prostor. Experimenty v umění šedesátých let, Praha 1999, s. 114-145.

63 Peter Cook, Experimental Architecture, New York 1970, s. 30-67.

${ }^{64}$ Josef Procházka, Experimentální ověrování ve výstavbě, Praha 1988. Publikace uvádí vyhlášku č. 79/1972 a vyhlášku Státní komise pro vědeckotechnický a investiční rozvoj č. 105/1985.

65 NA, fond KSĆ-ÚV-K 1945-1989, Komise pro řešení bytového problému 10/22, sv. 2, a. j. 9, zasedání 23. 5. 1960, Zpráva o komplexním vyhodnocení pokusných projektů bytové výstavby (Jiří Voženílek, Státní výbor pro výstavbu), s. 21. 
domů o první deskové a věžové domy o 8-10 patrech, které se dosud vůbec nestavěly. V rámci úvah o pestřejší typologii a o „druhovosti “ sídlištních staveb obživl také typ kolektivního domu, respektive domu hotelového bydlení.

Mezi úplné typologické novinky patřily objekty nižší a vyšší občanské vybavenosti neboli „distribuční centra“, „střediska obchodu, služeb a osvěty“ či později „obchodní centra“. Jejich charakter a velikost závisely na spádovém okruhu, pro který mělo centrum sloužit, na počtu obyvatel a na docházkové vzdálenosti. Podle daných výpočtů pak domy služeb nabízely odpovídající druhy prodejen, dále např́ílad restauraci, jídelnu či bufet, prádelnu, mandl, různé opravny, kadeřnictví, ale i kino, osvětový sál, čítárnu, poštu, případně služebnu Sboru národní bezpečnosti (SNB) či kancelář Obvodního podniku bytového hospodářství (OPBH). U větších obvodů se budovalo také zdravotní středisko. Na konci padesátých let přinesl časopis Architektura ČSR ochutnávku několika vzorových „prodejních středisek“ $\mathrm{z}$ výstavby sídliště Harlow ve Velké Británii či sídliště Vällingby ve Švédsku. ${ }^{66}$

Systém obytných skupin, okrsků a obvodů i rozsah jejich vybavení opakovaně rozpracovávala urbanistická skupina Výzkumného ústavu výstavby a architektury, zejména Julius Šif a Jaromír Štván. ${ }^{67}$ Cílem komplexně vybaveného sídliště bylo plošně uspokojit všechny životních potřeby jeho obyvatel, a jak upozorňuje Hubert Guzik, nabídnout demokratický př́istup ke službám. Výstižně sídliště označuje jako „kolektivní domy na ležato".68

Koncepce sídliště skutečně měla odrážet nebo dokonce akcelerovat budoucí „blahobytný“ život v komunismu. Zhmotňovala nový typ „humanizované“ socialistické kolektivity, přirozenou lidskou pospolitost vzdálenou heroické kolektivitě období stalinismu. Takový smysl spatřoval v experimentálních okrscích například Jiří Voženílek, který sídliště na půdě ƯV KSČ obhajoval slovy: „Ukazuje se, že společné zajištování některých služeb, zejména péče o děti, praní, př́padně př́prava pokrmü, by bylo výhodné a potřebné pro přvevážnou část domácností, protože je nejvíce potřebují zaměstnané ženy s více dětmi. Postupně bude třeba docílit vybavení podobné úrovně pro převážnou část všech bytů, a sice $v$ účelně sdružovaných objektech, sloužících nikoliv pro jeden düm, ale pro obytnou skupinu nebo celý obytný okrsek. Tomuto účelu může sloužit ovšem i vybavení, připojené př́mo k domu kolektivního charakteru a zároveň určené pro širši okolí. Tím by se také zajistil hospodárný provoz společenských částí kolektivního domu. "69

Voženílek vycházel z obdobného řešení československých projektů v soutěži na experimentální obvod v jihozápadní části Moskvy (Nové Čerjomušky), který komunistická strana po potřeby nového hodnocení experimentů nechala závazně posoudit. „Soutěž potvrdila zkušenosti získané z průzkumu, že kolektivní di̊m je investičně i provozně náročnějši než běžné typy bytových domů."70

Podíváme-li se na ně optikou centrálních plánovačů, domy hotelového typu, uskutečněné na počátku šedesátých let, mohly obstát jen tehdy, když suplovaly poskytované

66 Zdeněk Pexider, Prodejní střediska nová forma obchodního vybavení sídliště, Architektura ČSR XVIII, 1959, č. 3, s. 179-183.

67 Viz např. Jaromír Štván, Pravidla plánování a stavby sídlišt', Praha 1966.

${ }^{68}$ Hubert Guzik, Čtyři cesty ke koldomu, Praha 2014, s. 115.

69 NA, fond KSČ-ÚV-K 1945-1989, Komise pro řešení bytového problému 10/22, sv. 2, a. j. 9, zasedání 23. 5. 1960, Zpráva o komplexním vyhodnocení pokusných projektů bytové výstavby (Jiří Voženílek, Státní výbor pro výstavbu), s. 21.

70 Ibidem, s. 22. 
služby nových sídlišt nebo jejich škálu zpestřovaly. Takové opodstatnění nejlépe ilustruje dům hotelového typu postavený v rámci experimentálního okrsku v Praze na Invalidovně, jehož „synergii“ se sídlištní strukturou výstižně charakterizuje Hubert Guzik. Invalidovna zahájila také éru matematického plánování a statistického propočítávání sídlištní skladby bytů, domů a vybavení skupin a okrsků. V půdorysech domů architekti vycházeli z šetření Výzkumného ústavu výstavby a architektury, která doporučovala širší škálu kategorie bytů a nové možnosti dispozic s více pokoji. Nové dispozice oddělovaly různé provozy v bytě do samostatných místností, tím vznikly například menší neobytné ložnice, takzvané „pi̊lpokoje“ pro pracovnu či spaní dítěte nebo kuchyně s jídelním koutem. Takové uspořádání se sice jevilo jako praktické, ale vzhledem k bytové tísni se do menších bytů stěhovaly i vícečlenné domácnosti, pro které byt nebyl dimenzován.

Plánování bytů přerostlo do organizace obytného okrsku a „usměrňování“ života jeho obyvatel: volného času, vedení domácnosti či způsobu využívání služeb. ${ }^{71}$ Bytové domy, jejich vybavení a skladba bytů jasně definovaly, kdo a jak bude společné prostory a jednotlivé pokoje v bytě užívat. Palčivou otázkou pak zůstávala variabilita funkcí bytu v budoucnu. To měl vyřešit jakýsi tranzitní pohyb domácností napřrič sídlištěm. Lidé se měli stěhovat, ideálně $\mathrm{v}$ rámci sídliště, $\mathrm{v}$ momentě, kdy jim byt přestane vyhovovat, bude přiliš malý či velký. To se ale kvưli naprostému nedostatku bytů na volném „trhu“ nedělo. ${ }^{72}$ Zkušenosti brzy ukázaly, že vnitřní zákonitosti individuálního chování a jednání nelze direktivně řídit. Pokud chtěl socialismus připravit lidem ideální podmínky ve formě sídlišt', tak zcela podcenil fakt, který si západní architektura, filozofie a kulturní antropologie začala již plně uvědomovat: Příliš hotové struktury odpuzují a vedou k pasivnímu pojímání života a ignoraci veřejného prostoru.

Předpoklady, že materiální kultura prostředí se pozitivně odrazí i ve vztazích mezi lidmi a povede ke kýžené pospolitosti, se ukázaly jako př́liš ambiciózní a v podstatě mylné. Vzrůstající individualismus, atrofie mezilidských vztahů a egoistická touha po blahobytu, kterých si všímali sociologové na Západě, dopadly v následujícím desetiletí i na socialistickou společnost. Stoupající vědomí náležitosti jednotlivce k celku se nedostavilo, „socialistické vlastnictvi“ se čím dál více rozkrádalo, klesala pracovní morálka a pohoršení vzbuzovala také stoupající rozvodovost a sociální patologie (alkoholismus, vandalismus).

Podoba nových sídlišt vychází, jak shrnuje příručka Státní plánovací komise z roku 1960, z „možností perspektivního rozvoje našeho hospodárství a z vývojových tendencí bydlení. K racionálním východiskům přidává studie Výzkumného ústavu výstavby a architektury a Studijního a typizačního ústavu také úspěšné projekty československých týmů ze soutěže na experimentální obytný rajón pro jihozápadní část Moskvy. Poučení pro další vývoj projektů znělo, že „bytová výstavba není jen pasivní součást životního prostředí, ale že musí aktivně prispívat ke společenskému a hospodářskému pokroku naší socialistické společnosti." ${ }^{\text {73 }}$

71 Tehdejší urbanistické teorie vycházely např́ílad z kalkulace, jaké funkce lze zcela vyčlenit ze základních funkcí bytu. Vycházelo z toho jen vaření, respektive stravování, praní a čištění oděvů, úklid, provozování koníčkủ a kutilství.

72 Zmiňuje to rovněž Hubert Guzik v souvislosti s uplatněním kolektivního domu, viz Guzik (pozn. 68).

73 NA, fond KSČ-ÚV-K 1945-1989, Komise pro řešení bytového problému 10/22,sv. 4, a.j. 16, zasedání 6. 9. 1961, bod 6: Bulletin SPK o řešení bytového problému, s. 15 . 
Na vzniku nových typů se od roku 1961 podílel poprvé celý tým projektantů vybraných z krajských ústavů, ze Studijního a typizačního ústavu, z Výzkumného ústavu výstavby a architektury, Výzkumného ústavu stavební výroby a dalších institucí. Společné pracoviště vedl František Feistner. Není divu, že na nových typech T 05B-T 08B pracovali téměř všichni autoři předešlé vlny experimentů, například Václav Havránek (Praha), Štefan Svetko (Bratislava), František Steiner (Hradec Králové) nebo Jan Benda (České Budějovice). ${ }^{74}$ Nové typy schválily ústřední orgány v roce 1964, ale vzhledem k vyšším nárokům na výrobu a technologii stavby se začaly používat pozvolna.

Nové typové podklady umožnily stavbu velkých sídlišt’ a pestřejší řešení architektury i urbanismu. Do budoucna slibovaly přechod na prvkovou typizaci. Nakládání s typovými podklady v druhé polovině šedesátých let, kdy vzniká většina projektů „krásných“ sídlišt', měli architekti ve svých rukou. Nová reformovaná hospodářská soustava jim dávala větší pravomoci, těžiště zodpovědnosti za komplexní řešení projektů se přesunulo na konkrétní ateliér, který měl „zakázku“ na starosti. Kolektiv autorů pak mohl uzavírat smlouvy s dodavateli a stanovovat termíny. Změny se však neděly přes noc. Architekti nadále museli svádět boj s dodavateli a omezeným sortimentem výroby. Během zavádění nových ekonomických zásad po roce 1965 jejich pravomocná i společenská role a tím i vyjednávací pozice vưči výrobním podnikům výrazně zesílily. Architekti svými projekty moderních a „krásných“ sídlišt reprezentovali kýžené celospolečenské zájmy a pokrokové metody. „Společenské požadavky na výstavbu jsou vyjádřeny v projektu. Jak je však prosadit vưči monopolnímu dodavateli, jestliže trh nebude fungovat?" ptal se s obavami Jiří Klen v časopisu Československý architekt poté, co nasbíral dosavadní zkušenosti $\mathrm{s}$ „experimentem“ $\mathrm{z}$ hospodaření v krajích. „Žel, první vlaštovky nové soustavy se v praxi neuvedly dobře. Slyšel jsem při své cestě príliš často, že nové oborové podniky ve stavebnictví (vědomy si svého monopolního postavení) ř́kají na adresu architekta a investora ještě dürazněji než dřive: Vyberte si, bud’ toto, nebo nic. (...) Architekti a stavebníci se však dožadují druhé, hlavní stránky věci, která by umožnila odpověd: Ani toto, ani nic, zeptáme se jinde. $V$ obecných zásadách nové soustavy se tomu říká limitování subjektivních zájmů výrobcu společenskými zájmy prostřednictvím trhu. "75

$\mathrm{Na}$ špatné zkušenosti s dodavateli si stěžovala většina architektů šedesátých let. Václav Hilský v souvislosti s výstavbou sídliště Sítná v Kladně si na stránkách Československého architekta posteskl: „Třičtvrti roku válčím o lepší okna, než se mi podařilo je prosadit." "76 Typy T 06 B-T 08 B při troše snahy totiž umožňovaly osobitější architektonická řešení. Příčný nosný systém architektům uvolnil ruce při ztvárnění především fasád. Architekti vyvinuli výrazné úsilí typové projekty obohatit o řadu detailů, a tak dnes můžeme obdivovat několik sídlišt této „krásné fáze“ dějin hromadného bydlení. Kromě Sítné (Václav Hilský, Otakar Jurenka, Jiří Náhlík, 1961-1965) jmenujme ještě sídliště Labskou Kotlinu II v Hradci Králové (Břetislav Petránek a kolektiv, 1969-1975), sídliště Bory (Vladimír Belšán a kolektiv, 1963-1972) nebo sídliště Ruprechtice v Liberci (Josef Patrný, Miroslav Ulmann, 1969-1972).

${ }_{74}$ Jaroslav Pokorný, Nové typové podklady bytových domů, Architektura ČSSR XXI, 1962, s. 13-23.

75 Jiří Klen, Po slovech - činy, Československý architekt XII, 1966, č. 1-2, s. 1.

76 Diskuse o typizaci u hranatého stolu, Československý architekt, 1967, č. 25-26, s. 5. 


\section{Závěr}

Těžiště dizertační práce, ze které jsem vybrala uvedenou kapitolu, leží v době, kdy se typ panelového domu u nás teprve rodil a experimentálně se ověřovaly jeho vlastnosti. Architekt Julius Šif tehdy na stránkách časopisu Domov dobře charakterizoval úskalí tohoto bodu zvratu: „Výtvarně architektonické a urbanistické hledisko je na posledním místě experimentů, protože nemají ,vědeckoexperimentální povahu' (...). Má se opravdu vytvarné řě̌ení budovy vázat na specifičnost prostředí? Nestáváme se dnes svědky jakési neutralizace či univerzalizace architektury novostaveb hromadné výstavby? A možná že právě tato opakovatelnost se stává novou kvalitou, novou vlastností zítřejšího architektonického slohu!"77

Teoretik a historik umění Boris Groys si v souvislosti s nástupem paneláků všímá jejich univerzalistického charakteru. Vysvětluje jej utopistickou touhou východního bloku po univerzálním řešení, a jak píše, „všechna utopie směřuje $k$ bodu nula, $k$ asketickému, minimalistickému modelu a $k$ univerzalismu“ "78 Hledání typu bydlení, které bude dostupné všem a umožní sociální smír, tíhlo vždy k univerzálnímu řešení, k sériové výrobě a k opakování jednoho osvědčeného modelu. Období po druhé světové válce u nás, jak se snažím v práci přiblížit, se nespokojilo jen s jednou univerzální konstrukcí paneláku, jak by se na základě pozdější praxe mohlo zdát. Architekti a mnozí autoři experimentů prosazovali například prefabrikaci in situ a monolitní konstrukce, které by umožňovaly sice univerzální, ale mnohem variabilnější typy staveb. Také prosazovaná prvková typizace počítala s otevřeným skladebným systémem umožňujícím pestré pojetí hmot, fasád a povrchů. Dlužno říci, že právě jednotvárnost prvních univerzálních typů bytovek postavených v padesátých letech, jejich asketická forma redukovaná na pouhé panelové krabice s okny, nevyhovovala tehdy téměř nikomu. Otevřeně ji kritizovali architekti - např́klad Osvald Döbert či Karel Prager -, ale i členové Komise pro řešení bytového problému při Ústředním výboru KSČ a obyvatelé, kteří se o ní nechvalně zmiňovali během první celostátní diskuse o bydlení. V roce 1960, kdy diskuse vrcholí a připravuje se dokonce její druhá fáze, jsme svědky zajímavého okamžiku převrstvování názorů. V doznívající atmosféře ekonomického růstu a $\mathrm{v}$ opojení $\mathrm{z}$ nově nastoupeného procesu demokratického centralismu se na krátký moment zdá, že všichni, včetně politické reprezentace, usilují o totéž - o zlepšení bydlení, o vyšší bytový standard, ale také o esteticky(!) kvalitní prostředí. Politbyro ÚV KSČ přijalo v roce 1960 směrnici o navýšení bytového standardu a pro výstavbu do budoucna výrazně zvýšilo podíl vícepokojových bytů. Slibně se rozvíjející vlnu experimentů zaměřených i na estetické kvality bohužel ústřední orgány dále nevyužily. Plánovači nebyli schopní sledovat v hodnocení architektury jiné než ekonomické bilance a jednostranné cíle. Kvality jednotlivých experimentálních domů i jejich technologií nazírali jen optikou čísel, produktivity práce, kubických metrů betonu a podobně. Ovšem i tato čísla, jak ukazuji v práci, byla více než chimérická; nikdy tak vlastně nebyla dotažená kompletní ekonomická bilance, která by vyzdvihovala jeden konstrukční systém jako nejvýhodnější.

\footnotetext{
Julius Šif, Architekti experimentují, Domov II, 1961, č. 1, s. 43.

78 Boris Groys, Panel houses: Stations on the way to utopia, in: Pedro Alonso - Hugo Palmarola (eds), Monolith Controversies. Pavilion of Chile, Ostfildern 2014, s. 46-47.
} 
Nedá se tedy jednoznačně říct, že právě panelák, systém montovaný z panelů, pro který se mocenské centrum po skončení experimentů rozhodlo, splňoval nejlépe všechna kritéria univerzalismu. Plížící se hospodářské problémy, roztříštěnost výroby, nedostatek materiálů a strojů, to všechno v každém př́ípadě ústř̌ední orgány v roce 1962 dovedlo $k$ přesvědčení, že nejlépe vše vyřeší direktivní plán, opětná centralizace a vybudovaná sít paneláren, neboli jednotná materiálně-technická základna. Technokraticky pojatému univerzalismu stavební typ montovaný z prefabrikovaných panelů vyhovoval nejlépe.

\section{SUMMARY}

\section{Panelak as a product of the scientific experiment}

The presented text concerns selected topics on flat construction in the 60's - experiments and prefabricated housing estates in former Czechoslovakia - and examines them in broader context.

The viewpoint of state socialism and its ideology stemmed from the situation, when architecture in the whole socialistic block seized to be the instrument of social reform on the promoted path to communism. This opinion, projected on an economic level, lead to an assumption that an affordable and high-quality housing makes the society effectively economically modernized.

The living in new housing estates in late 50's was intended to become the "display window" of the socialist lifestyle as well as the means of a morally higher type of consumer society.

In the atmosphere of socialist utopia during the 60 's, the housing estates were planned to compete with the West and to create to it an alternative, which would be socially, technically and esthetically flawless.

The text is dedicated to technological and construction experiments, conception of a housing district (residential group) and to the example of the "beautiful" panel housing estates. It ponders the relationship of the Czechoslovakian panel house and the system of districts to the soviet example.

From the artistic and historic viewpoint, it deals with the relation of construction systems and fabrication to the concrete design of the housing estate at a point, when an overly schematic (functionalist) view fails and is replaced by a view that is complex and humanistic.

\section{VÝBĚROVÁ BIBLIOGRAFIE}

Constructed Happines. Domestic Enviroment in the Cold War Era, Tallinn 2005

Peter Cook, Experimental Architecture, New York 1970, s. 30-67.

Michal Čech, Vývoj komplexnej kvality panelových domov, Pozemní stavby XII, 1964, č. 7, s. 276-281.

Vlastimil Čuhel, Kvádrová výstavba, Architektura ČSR XVI, 1957, č. 4-5, s. 164.

Diskuse: K experimentálnímu projektování, Architektura ČSSR XIX, 1960, s. 559.

Diskuse o otázkách soudobé výstavby a architektury v SSSR I a II, VÚVA Praha 1955.

II. všesvazový sjezd sovětských architektů. Sborník přeložených materiálů, Praha 1955. 
Boris Groys, Panel houses: Stations on the way to utopia, in: Pedro Alonso - Hugo Palmarola (eds), Monolith Controversies. Pavilion of Chile, Ostfildern 2014, s. 46-47.

Hubert Guzik, Čtyři cesty ke koldomu, Praha 2014.

Jan Hanzlík - Jana Zajoncová - Lenka Hájková, Teplice: Architektura moderní doby 1860-2000, Ústí nad Labem 2016.

Steven E. Harris, Communism on Tomorrow Street. Mass Housing and Everyday Life after Stalin, Baltimore 2013.

Václav Havránek - Miroslav Růžička, Monolitický krabicový obytný dům, Pozemní stavby VI, 1958, č. 10, s. 515-521.

Karel Janů, K otázce montovaných bytových staveb, Architektura ČSR XIII, 1954, s. 35-41.

Rostislav Koryčánek (ed.), Na prahu zitř̌ka. Brněnská architektura a vizuální kultura v období socialismu, Brno 2014.

Alois Kreuzer, Experimentální projekty a stavby pro zajištění hromadné bytové výstavby, Československý architekt V, 1959, č. 15-19, s. 2.

Philipp Meuser - Dimitrij Zadorin, Towards a Typology of Soviet Mass Housing. Prefabrication in the USSR 1955-1991, Berlin 2015.

Virag Molnar, In Search of the Ideal Socialist Home in Post-Stalinist Hungary: Prefabricated Mass Housing or Do-It-Yourself Home?, Journal of Design History XXIII, 2010, No. 1, s. 61-81.

Ákos Moravánszky - Judith Hopfengärter, Re-Humanizing Architecture: New Forms of Community, 1950-1970, Vol. I, Basel 2017.

Hugo Palmarola - Pedro Ignacio Alonso, Tropical Assemblage. The Soviet Large Panel in Cuba, in: Beyond Imported Magic. Essays on Science, Technology and Society in Latin America, Cambridge, Mass. 2014, s. 159-179.

Zdeněk Pexider, Prodejní stř̌ediska nová forma obchodního vybavení sídliště, Architektura ČSR XVIII, 1959, č. 3, s. 179-183.

Karel Prager, Upravený panelový dům G 57, Architektura ČSSR XXI, 1962, č. 5, s. 295-297.

Lucie Skřivánková - Rostislav Švácha - Eva Novotná - Karolina Jirkalová (eds), Paneláci 1. Padesát sídlišt v českých zemích. Kritický katalog k cyklu výstav Příběh paneláku, Uměleckoprůmyslové museum v Praze 2016, s. 172-179.

Karel Storch, Pokusný bytový dům o 11 podlažích v Brně, Architektura ČSSR XX, 1961, č. 5, s. 307-314.

Oldřich Strádal, Bytová výstavba ve Skandinávii, Pozemní stavby VI, 1958, č. 5, s. 266-271.

Julius Šif, Poznámky o některých kompozičních otázkách a o výtvarném řešení obytných budov, Architektura ČSSR XX, 1961, s. 260.

Jaromír Štván, Pravidla plánování a stavby sídlišt', Praha 1966.

Rostislav Švácha - Ludmila Hájková, Kde budeme žít zítra, in: Vít Havránek (ed.), Akce slovo pohyb prostor. Experimenty v umění šedesátých let, Praha 1999, s. 114-145.

Ludevít Végh, Montované stavby, Praha 1959.

Miloslav Wimmer, Panelové domy s montovaným skeletem, Praha 1956. 


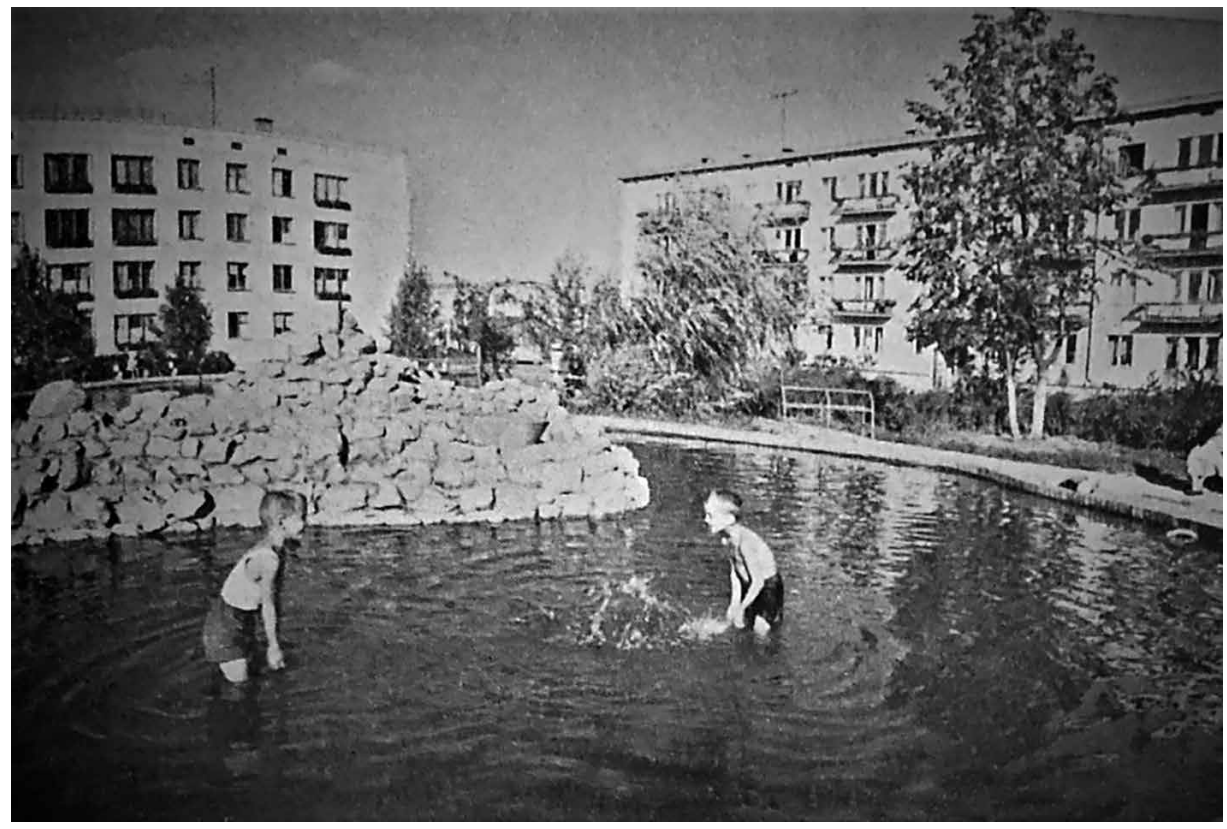

Obrázek 1. Obytný okrsek č. 9, Nové Čerjomušky, Moskva. Reprodukce z časopisu Pozemní stavby VIII, 1960, č. 5

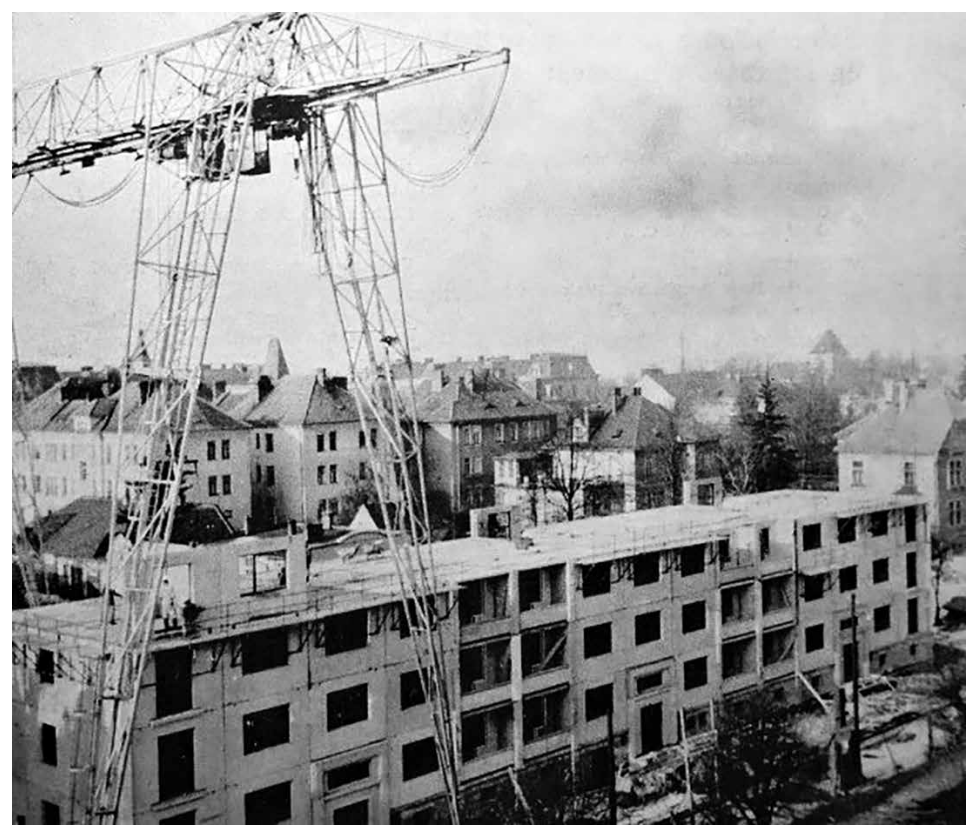

Obrázek 2. Montáž prototypu G 57 v Opavě s pomocí portálového jeřábu, 1958. Reprodukce z časopisu Pozemni stavby VI, 1958, č. 5 


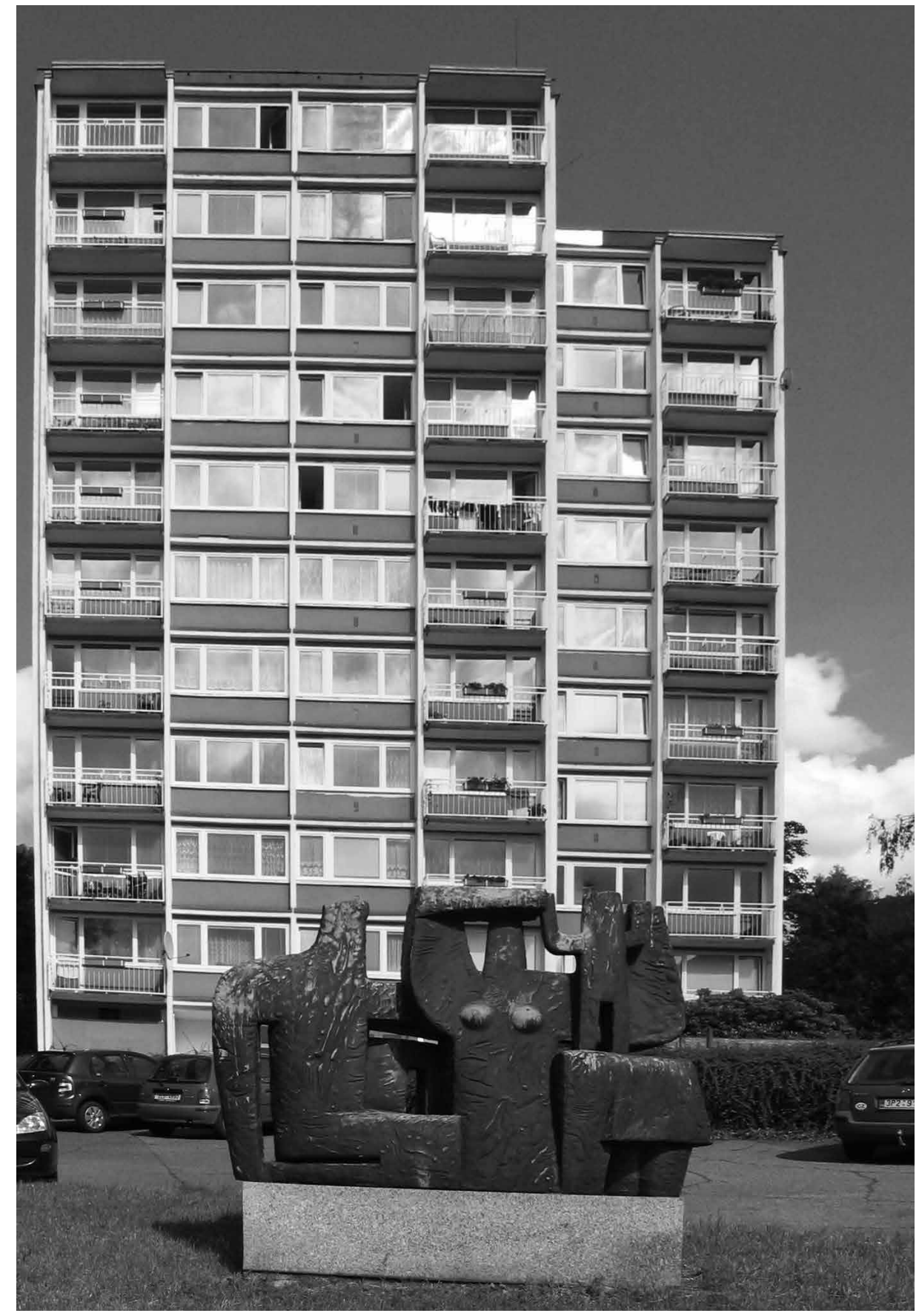

Obrázek 3. Jaromír Vacek, sídliště Králův Háj, Liberec, 1959-1963. Snímek Eva Novotná 


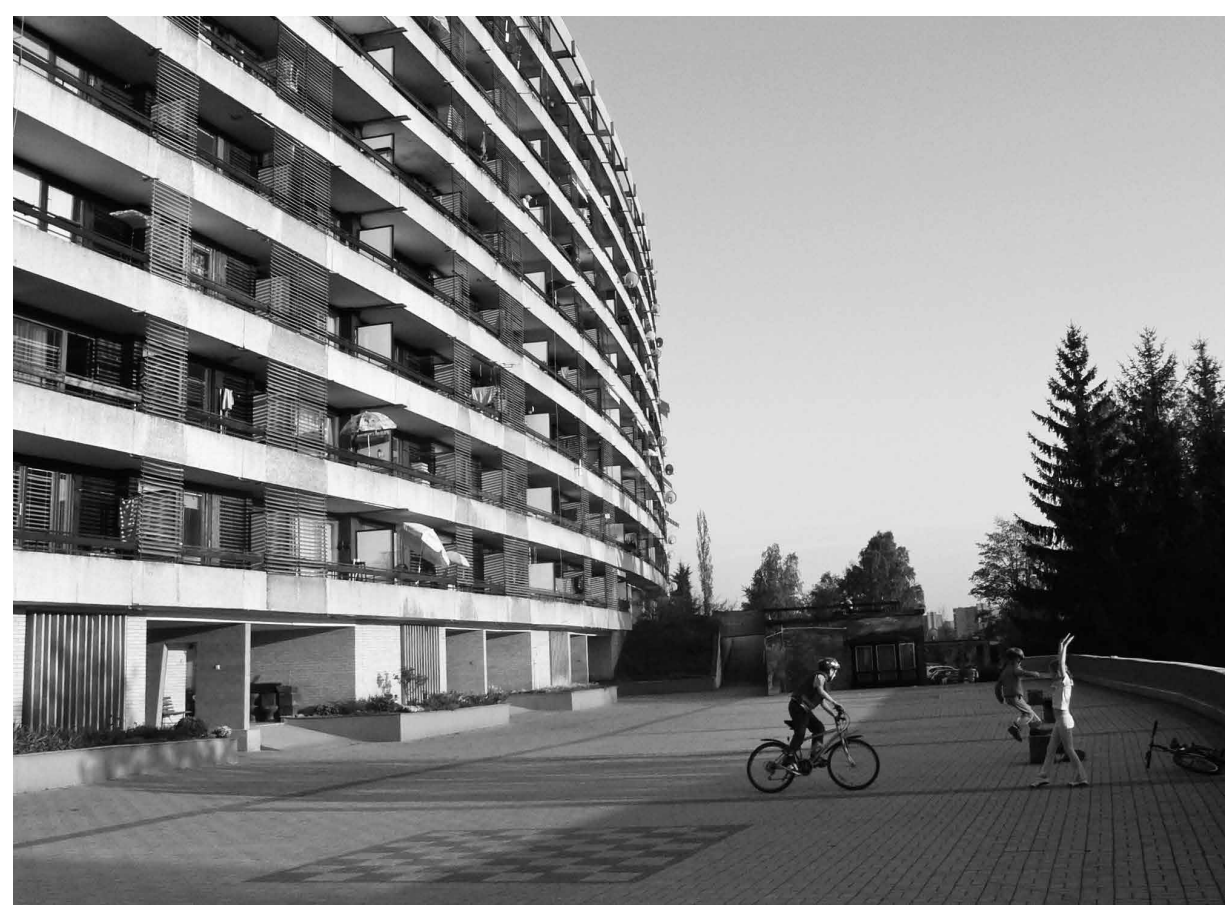

Obrázek 4. Jaromír Vacek - Václav Voda, sídliště Králův Háj, Liberec, 1968-1972. Snímek Eva Novotná 

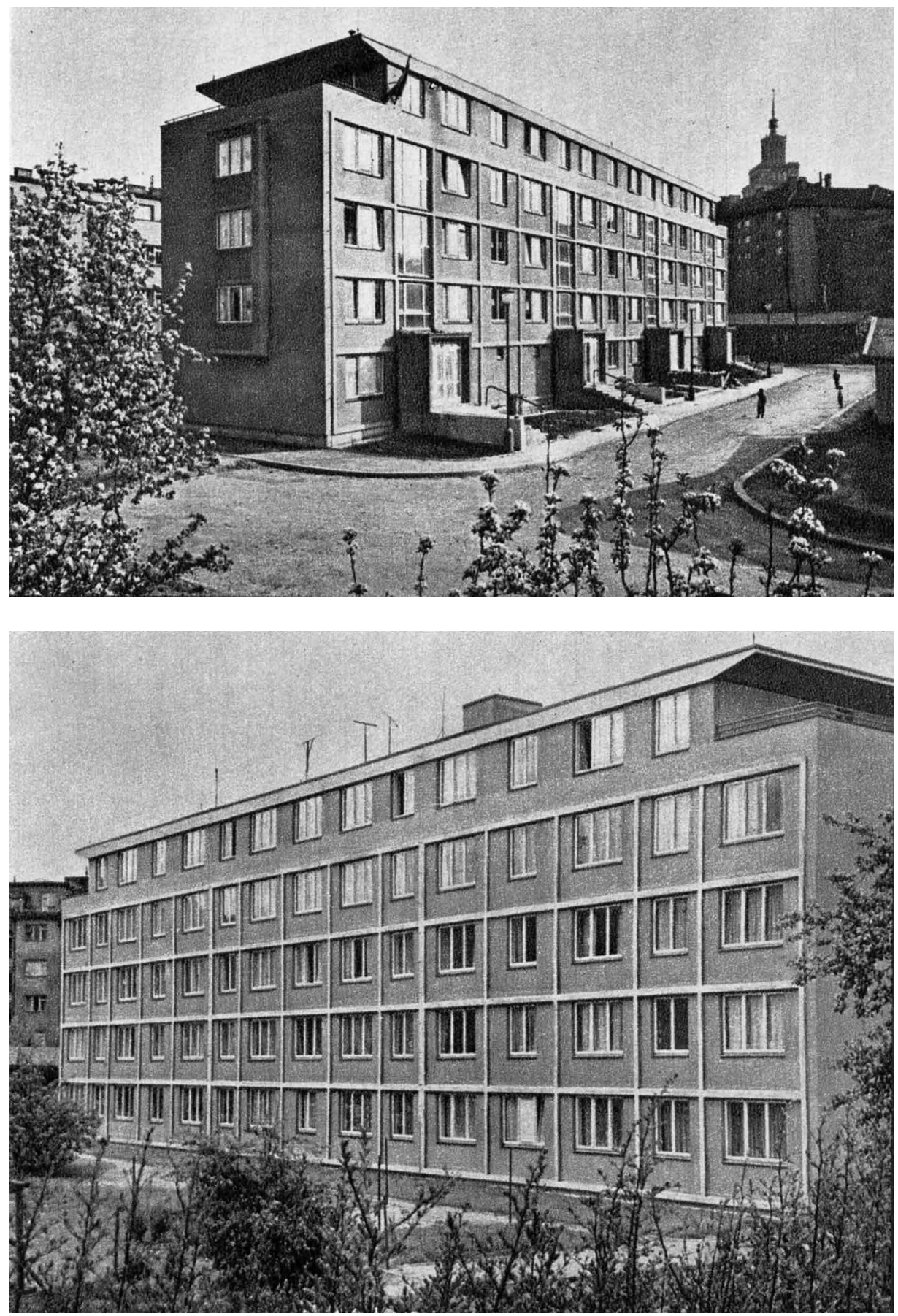

Obrázek 5. Václav Havránek - Miroslav Růžička, experimentální dům, Praha-Bubeneč, 1958-1959. Reprodukce z časopisu Domov I, 1960, č. 6 


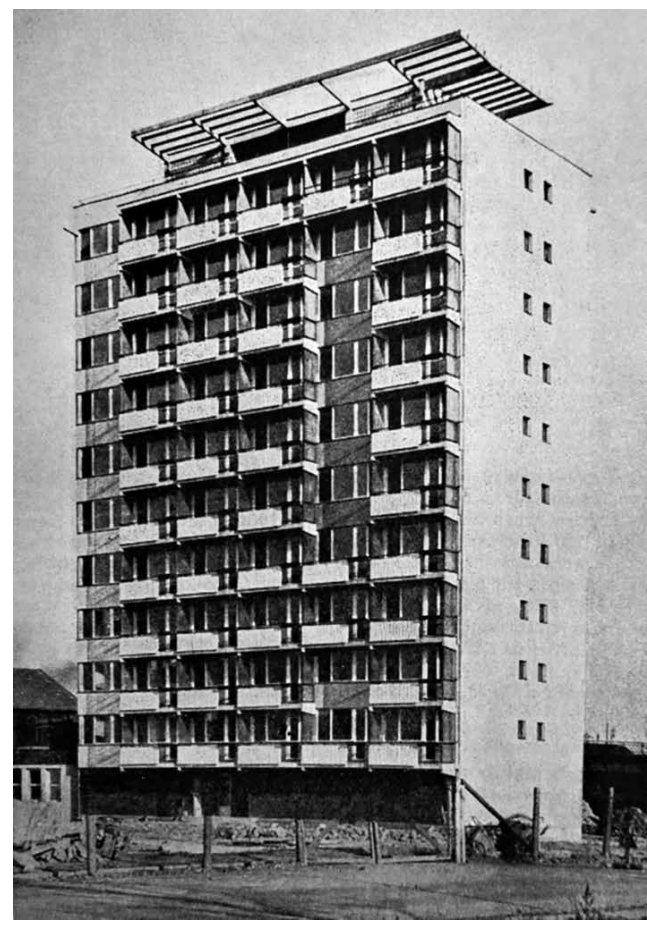

Obrázek 6. František Zounek - Milan Pospíšil, experimentální dům, Brno, Křídlovická ulice, 1958-1961. Reprodukce z časopisu Pozemni stavby IX, 1961, č. 7

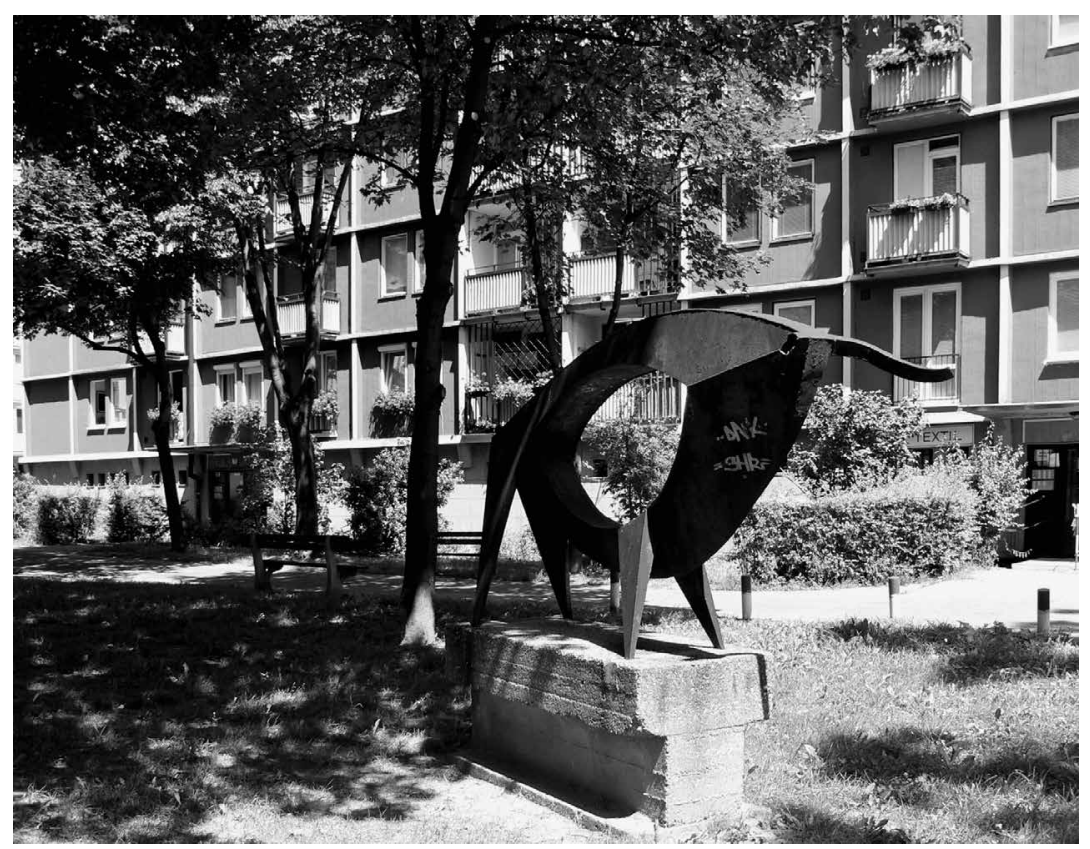

Obrázek 7. Štefan Svetko - Ondřej Dukát a kol., sídliště Februárového vítazstva, Bratislava, 1953-1961. Snímek Eva Novotná 


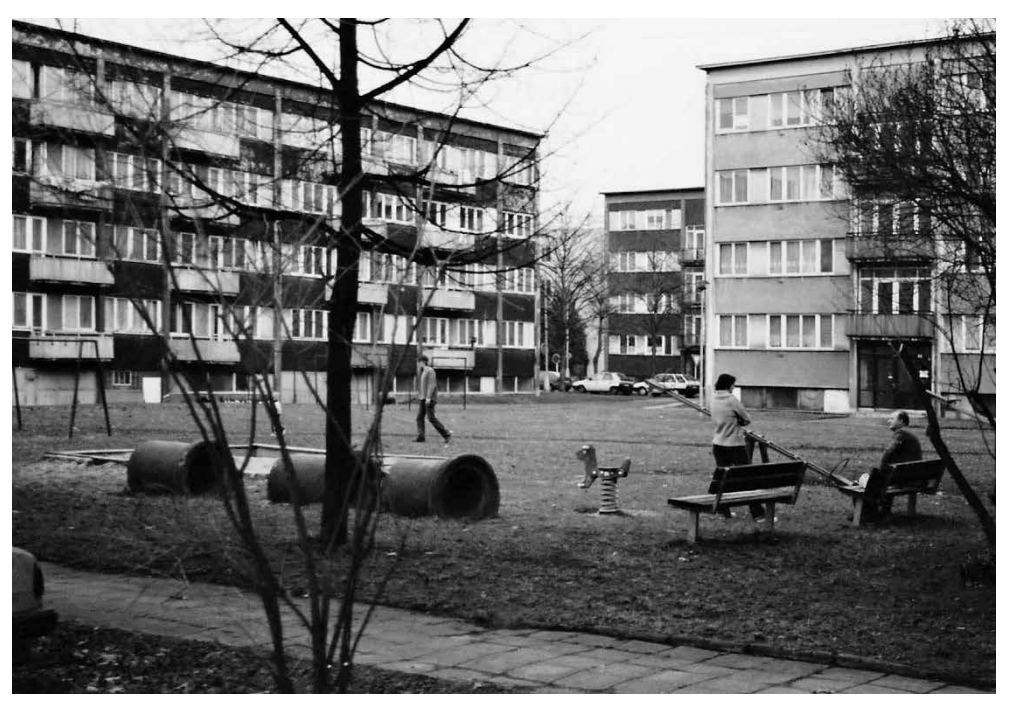

Obrázek 8. František Steiner - Jaroslav Škaloud - Jan Zídka, sídliště Slezské Předměstí, Hradec Králové, 1956-1962. Snímek Eva Novotná

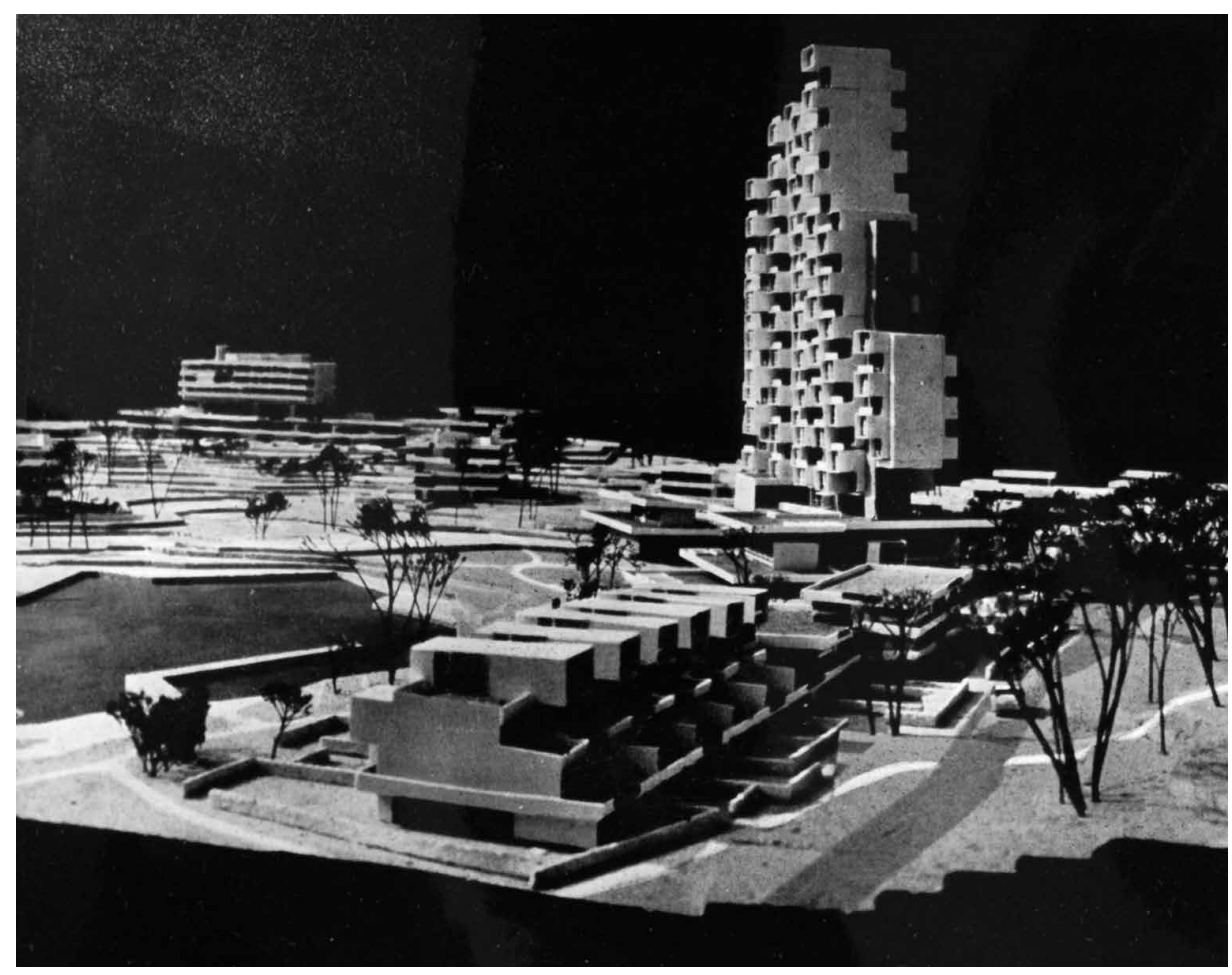

Obrázek 9. Gorazd Čelechovský a kol., projekt Etarea, 1967. Reprodukce z knihy Gorazda Čelechovského, Etarea: étude du milieu humain dans la ville, Institut d'études de la Ville de Prague, 1967 